
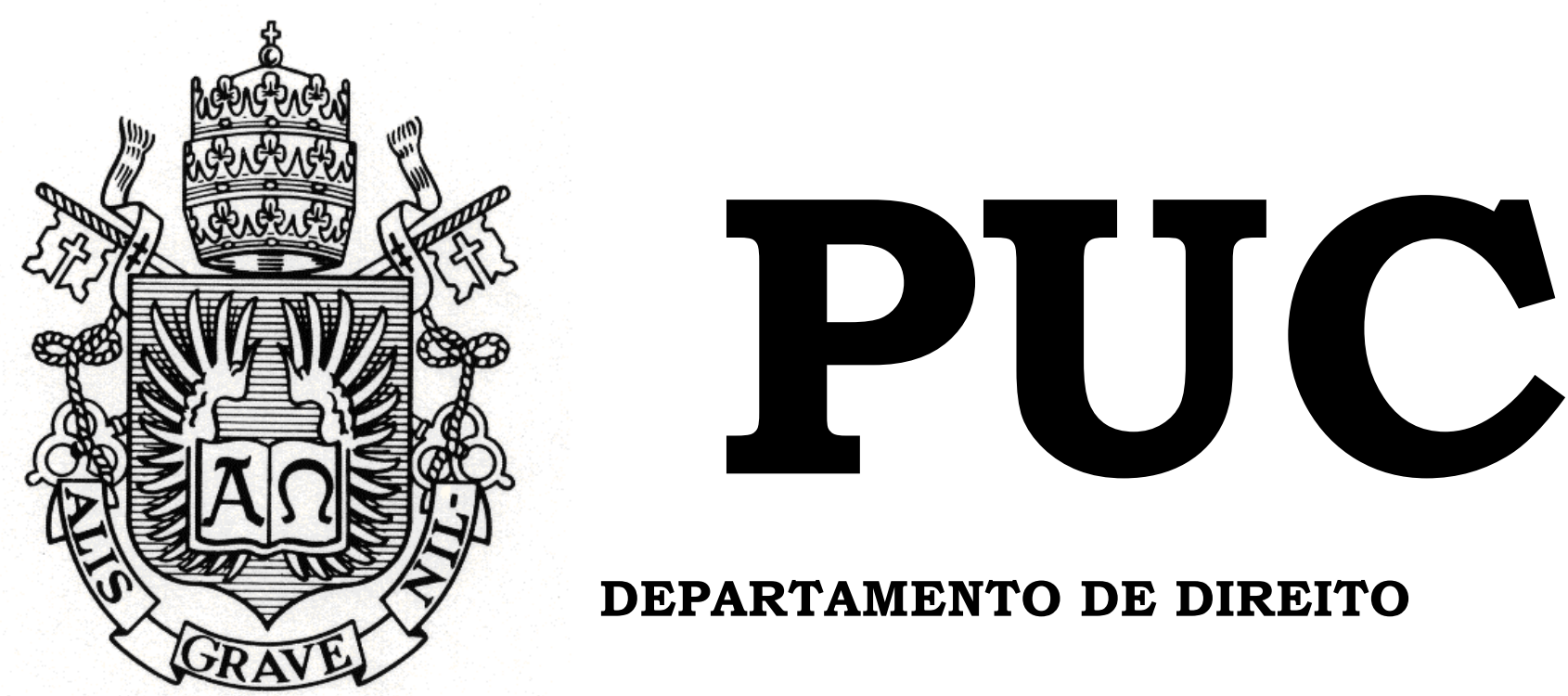

DEPARTAMENTO DE DIREITO

\title{
RACISMO INSTITUCIONAL E PODER JUDICIÁRIO: O IMPACTO DA ATUAÇÃO JURISPRUDENCIAL DO TJRJ NA MANUTENÇÃO DAS DESIGUALDADES RACIAIS
}

por

CAROLINE LYRIO

ORIENTADORA: Thula Pires

2012.2

PONTIFÍCIA UNIVERSIDADE CATÓLICA DO RIO DE JANEIRO

RUA MARQUÊS DE SÃO VICENTE, 225 - CEP 22453-900

RIO DE JANEIRO - BRASIL 


\section{RACISMO INSTITUCIONAL E PODER JUDICIÁRIO: O IMPACTO DA ATUAÇÃO JURISPRUDENCIAL DO TJRJ NA MANUTENÇÃO DAS DESIGUALDADES RACIAIS}

por

CAROLINE LYRIO

Monografia apresentada ao Departamento de Direito da Pontificia Universidade Católica do Rio de Janeiro (PUC-Rio) como requisito parcial para a obtenção do Título de Bacharel em Direito.

Orientadora: Thula Pires 
Aos meus avós, Maria José e Jorge Maria,por terem cultivado-incansavelmente - a busca pelo saber. 


\section{Agradecimentos}

Primeiramente e acima de qualquer coisa, aos meus pais Mara e Ricardo. Por terem sido a mão que afaga e a mão que alerta, pelo apoio incondicional e por terem me ensinado a fé que me sustenta.

À minha irmã Jessica, pela amizade sem barreiras e fronteiras, principalmente nos últimos anos.

Ao meu irmão João Victor, fonte diária de ensinamento, o menino e moleque que vem me dar a mão.

À minha avó, pela coragem e pela força, por não se submeter. Ao meu avô, meu primeiro super-herói, por me ensinar sobre invasões, guerras e templários como se fossem pequenos contos infantis.

À minha madrinha Tatiana, por provar que a presença independe da distância.

Aos amigos Elaine Maria, Elisiane Soares, Fernanda Souza e Yuri Muniz, partes tão constantes e essenciais dessa graduação que qualquer agradecimento jamais será capaz de exprimir a minha gratidão pelas mãos estendidas e ombros oferecidos.

Aos companheiros de luta no grupo de pesquisa Felipe Arêas e Kamila Souza pelo apoio, pelas discussões tão engrandecedoras e pelos ensinamentos.

A todos os professores ao longo da graduação, elementos tão importantes para o meu crescimento intelectual e como ser humano, mas, com um carinho especial, a dois mestres: André Perecmanis por toda paixão, eloquência e senso crítico durante suas aulas e por, com isso, ter me trazido "de volta" para o Direito em um momento no qual eu acreditava não ter mais futuro ou razão persistir e Juliana Bracks pelo carinho, atenção, palavras de apoio e, principalmente, pela amizade.

À minha querida orientadora Thula Pires, pela paciência, persistência, paciência, persistência (repetidos mesmo!), eterna disponibilidade, por ter 
apostado no meu trabalho, pelos elogios e cascudos certeiros. Muito obrigada por tudo! Eu jamais teria conseguido sem a sua ajuda.

Por fim, aos meus amigos-irmãos Carolina Câmara Pires e Alexandre Silva pelas lágrimas e sorrisos. Com a ousadia de citar Shakespeare, digo para vocês: "For he that sheds his blood with me / Shall be my brother". 


\section{Resumo}

O presente trabalho se propõe a analisar as decisões proferidas em grau recursal pelo Tribunal de Justiça do Estado do Rio de Janeiro acerca de litígios envolvendo a prática de discriminação racial contra negros na seara criminal, procurando demonstrar a existência de um racismo institucional no interior do Poder Judiciário Fluminense. Objetivando uma melhor contextualização da problemática racial na sociedade brasileira, iniciamos expondo um breve histórico de como o negro se torna 'a questão' e avançamos para uma abordagem da evolução do pensamento teórico-ideológico pátrio que serviu como justificativa para a prática discriminatória ao longo dos anos, destacando autores-chaves em cada período. Em seguida, elencamos o que consideramos como marcos essenciais no avanço da legislação constitucional-penal que aborda a criminalização da discriminação no cenário jurídico brasileiro. Finalmente, apresentamos a análise processual das decisões proferidas entre os anos de 1989 e 2011 no TJRJ, identificando a legislação utilizada, a natureza dos argumentos suscitados, o tempo de tramitação e o resultado final em cada caso, aplicando os pressupostos teóricos da Teoria Crítica da Raça na análise dos dados extraídos, explicitando o enraizamento do racismo na sociedade brasileira como um todo.

\section{Palavras-chave}

Discriminação - Racismo - Teoria Crítica da Raça 


\section{Sumário}

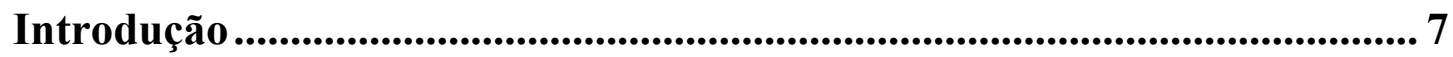

Capítulo 1 - Pensamento Racial Brasileiro ............................................................. 10

1.1 O Negro como questão ...................................................................... 10

1.2 Evolucionismo e darwinismo social ........................................................ 13

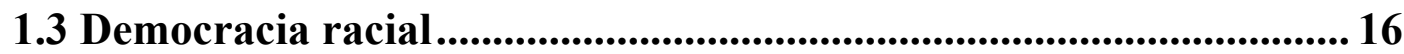

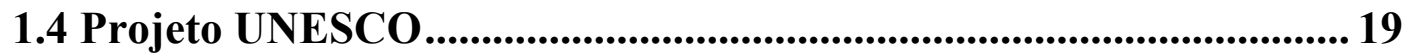

1.5 Discussão contemporânea .................................................................. 23

Capítulo 2 - Legislação Penal BrasileiraAntidiscriminação ......................... 25

2.1 A histórica criminalização do negro .......................................................... 26

2.2 Lei Afonso Arinos ................................................................................................ 28

2.3 Carta Magna de 1988 ...................................................................................... 30

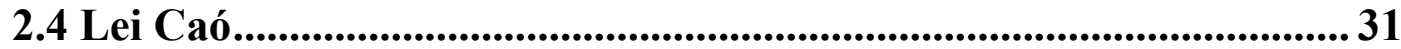

2.5 Injúria Qualificada.......................................................................................... 32

Capítulo 3 - Agulha no Palheiro: A Aplicação Penal da Legislação Antidiscriminação pelo TJ-RJ .................................................................................. 34

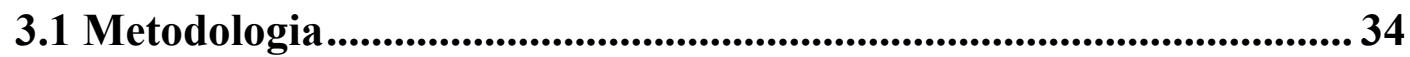

3.2 Apresentação e análise dos dados .............................................................. 37

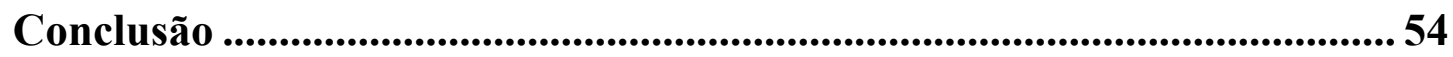

Referências Bibliográficas .......................................................................................56 


\section{Introdução}

No que diz respeito à existência de um cenário de múltiplas desigualdades que assola a realidade de uma grande parte da sociedade brasileira, há um consenso. Entretanto e, principalmente inspirados nos dados divulgados pelo Relatório Anual das Desigualdades no Brasil 2009-2010 organizado por Marcelo Paixão, Irene Rosseto, Fabiana Montonavele e Luiz M. Carvano, começamos a questionar porque encontramos "realidades jurídicas paralelas entre negros e brancos", ${ }^{\text {, }}$ principalmente no Brasil, que sempre foi identificado como um país de convivência harmônica entre as diversas "raças" que o compõem.

Partindo-se da hipótese central de que ao longo da história legislativa brasileira foram criados uma série de mecanismos que buscavam legitimar práticas discriminatórias contra negros e motivados pela quase inexistência de produção no que tange à análise da situação racial brasileira sob o enfoque jurídico, optamos por iniciarmos uma análise da aplicação da legislação antidiscriminação pátria.

A maneira encontrada para atingirmos tal propósito encontrou guarida no Programa de Iniciação Científica da Universidade, dentro da linha de pesquisa "O Papel do Direito na Perpetuação das Desigualdades Raciais no Brasil", que analisa o impacto de práticas racialmente discriminatórias no comportamento dos Poderes Judiciário e Legislativo brasileiros.

Nesse sentido, o objetivo geral do presente trabalho é avaliar, a partir de uma pesquisa empírica, as diferentes interpretações e aplicações da legislação antidiscriminação dadas pelo Poder Judiciário Fluminense de acordo com as noções de racismo institucional e racismo estrutural, de forma a iniciar uma análise jurídica da legislação pátria tendo a raça como elemento constitutivo

${ }^{1}$ PAIXÃO, Marcelo. Manifesto Anti-Racista: ideias em prol de uma utopia chamada Brasil. 1a ed. Rio de Janeiro: DP\&A; LPP/UERJ, 2006. p. 69. 
essencial para uma melhor compreensão da realidade social, buscando, com isso, um aprimoramento dos textos legislativos.

Para alcançarmos tal proposta, optamos por apresentar uma contextualização do ordenamento jurídico pátrio, pontuando marcos - teóricos e legislativos - que nos trouxeram ao patamar atual de combate à discriminação contra negros. Assim, iniciamos o primeiro dos três capítulos que nos propomos a apresentar, com uma abordagem mais histórica de como o negro se transformou e continua sendo representado no imaginário nacional. Focando na realidade brasileira, mas fazendo um encadeamento com acontecimentos mundiais sempre que necessário, apresentaremos a evolução teórico-ideológica que embasou o pensamento racial pátrio desde o fim do século XIX. Importante salientar que, em nossa análise, não nos ateremos aos autores estrangeiros chamados 'brasilianistas'.

Em seguida, incentivados pelas premissas e objetivos da Teoria Crítica da Raça (TCR), utilizada como marco teórico em nossa análise, focaremos em um viés mais jurídico formal, elencando o que consideramos como principais marcos na história da legislação antidiscriminação brasileira, demonstrando a influência material de todo o pensamento teórico-ideológico abordado no capítulo anterior. Iniciaremos nas Ordenações Filipinas, que regeram o país por quase duzentos anos, até alcançarmos a introdução do delito de injúria qualificada no Código Penal Brasileiro em 1997.

Finalmente, estabelecidas as bases para um melhor entendimento, $\mathrm{o}$ terceiro e último capítulo, apresentará o resultado da pesquisa realizada, destrinchando as decisões proferidas nos acórdão e extraindo os dados, por nós considerados mais relevantes, e que nos gabaritarão para responder às questões levantadas.

$\mathrm{Na}$ parte empírica, nossa pesquisa restringiu sua análise à processos judiciais em nível recursal que envolveram a prática de discriminação racial contra negros encontrados no Poder Judiciário Fluminense e buscou examinar 
se existe e de que forma o racismo estrutural/institucional expande-se para o interior de uma instituição de essencial importância dentro de um Estado Democrático de Direito como o Poder Judiciário. 


\section{Pensamento Racial Brasileiro}

\subsection{Negro como Questão}

Embora com características e justificativas distintas, a figura do escravo sempre esteve presente na história da humanidade. Contudo, os contornos para chegarmos a ideia moderna de escravidão começaram a ser desenhados no momento em que a cor da pele passou a ser utilizada como fator de exclusão. Tal nuance transformaria, mais tarde, a "escravidão (aparato legal permitindo, aqui e acolá, a redução do produtor direto a propriedade privada) [...] em escravismo (sistema produtivo colonial fundado na escravidão e integrado à economia-mundo) $)^{2}$

Ao analisarmos a história mundial, pudemos enxergar que, em um primeiro momento, a cor esteve associada a uma contextualização religiosa e encontramos na expansão árabe-mulçumana no séc. VII elementos de grande relevância para o conceito atual de escravidão: i)os árabes foram os primeiros a montarem uma rede de tráfico de escravos de longa distância, ii) relacionavam, de forma geral, 'cores escuras/mal e moralmente condenável' e 'branco/divino e puro de fé e iii) o islã proibia a escravização de pessoas que professassem a sua fé, fazendo com que a chegada de escravos oriundos de regiões mais ao oriente e com compleições físicas diferentes, potencializasse o processo de diferenciação do outro ${ }^{34}$.

Conquistada pelos árabes ainda no séc. VIII, a península ibérica foi durante cerca de 700 anos ponto de encontro entre cristãos e mulçumanos,

\footnotetext{
${ }^{2}$ ALENCASTRO, Luiz Felipe de. O trato dos viventes: formação do Brasil no Atlântico Sul. São Paulo: Companhia das Letras, 2000. pag. 32.

${ }^{3}$ Argumentos trazidos em HOFBAUER, Andreas. Uma história de branqueamento ou o negro em questão. São Paulo: Editora UNESP, 2006.

${ }^{4}$ A proibição da escravização de povos islamizados foi superada através do discurso da 'Maldição de Noé' - passagem da Bíblia onde diz que Noé teria amaldiçoado Canaã por tê-lo visto nu e, consequentemente, todos os descendentes de Canaã, no caso aqueles de pele escura, estariam amaldiçoados também - permitindo que povos subsaarianos pudessem ser escravizados. Tal justificativa também foi utilizada no princípio do comércio negreiro atlântico.
} 
introduzindo no imaginário português a figura do 'mouro' - escravo mulçumano - como a figura padrão do escravo, sem que houvesse qualquer menção a cor de pele. O termo 'preto' surge apenas no séc. XVI para designar o escravo batizado provindo da África não-cristã, em oposição ao escravo mulçumano.

Durante o séc. XV, através do ataque a Ceuta em 1415 ou na reta final da reconquista cristã, que culminou com a expulsão dos mulçumanos da península, Portugal adquire poder sobre terras africanas e ilhas atlânticas, iniciando sua exploração, principalmente na África, a procura de metais preciosos que sustentassem suas atividades mercantis com a Índia, Ásia e o Império Otomano. $\mathrm{O}$ comércio escravista era utilizado como moeda de troca com povos africanos por ouro, prata e cobre ${ }^{5}$.

No entanto, o princípio da produção açucareira nas colônias portuguesas (iniciada pelas ilhas atlânticas de Madeira e Açores) e a exploração espanhola no Novo Mundo, mudariam de forma drástica o destino do negro africano. $\mathrm{O}$ tráfico passa de uma moeda de troca a fonte de receita para a Coroa portuguesa. Não apenas isso. Sem conseguir ter o controle sobre a circulação de mercadorias proveniente de suas colônias, Portugal encontra no tráfico negreiro a forma de controlar o processo produtivo americano: "os colonos devem recorrer à Metrópole para [...] importar seus fatores de produção, isto é, os africanos"

\footnotetext{
5“As primeiras expedições na África têm o intuito de procurar jazidas e feiras nativas onde se permutavam metais preciosos. Com o fito de obter o ouro do rio Níger, os portugueses trocam com nativos vizinhos da fortaleza construída em 1482 em São Jorge da Mina [...] escravos trazidos do litoral oeste (do Benim), inaugurando o trato negreiro marítimo naquelas partes africanas." Nesse sentido, ver ALENCASTRO, Luiz Felipe de. O trato dos viventes. pag. 30.

${ }^{6}$ Ibid. p. 27-28. O Autor destaca que "O controle espanhol repousa pouco sobre o processo de produção e bastante sobre a circulação das mercadorias. Metais preciosos, os produtos das colônias espanholas podiam ser estocados e transportados num sistema de frotas [...]. Na Terra de Santa Cruz as coisas tomam outro rumo. A concentração das trocas em alguns portos e as longas esperas na compra, armazenagem e transporte de mercadorias, típicos do modelo espanhol, pareciam inadequadas à natureza perecível e fungível dos produtos agrícolas e as flutuações de preços. Ademais, os portos secundários [colônias] portugueses participavam do comércio oceânico, complicando o estabelecimento do monopólio das trocas em Lisboa ou no Porto."
} 
Mesmo com a influência econômica na ampliação do trato negreiro, o modelo continuava a ser justificado pelo viés religioso, de tal forma que a exclusão pela cor voltou a ser justificada pela "Maldição de Noé", reavivada de tradições judaicas e mulçumanas ${ }^{7}$.

A partir do séc. XVII, o enfraquecimento das coroas europeias e o fortalecimento da burguesia mercantil, particularmente com o despertar do Iluminismo, propiciaram o surgimento de teorias que procurariam justificar a exclusão pela cor não mais pelo caráter religioso, e sim através de uma abordagem mais científica (razão) ${ }^{8}$.

Com isso, ao longo do séc. XVIII surgiram teorias, como a de George de Buffon (1707-1788), de que a cor da pele estava diretamente ligada a condições climáticas e geográficas, sendo a cor branca o "normal" na espécie humana e qualquer outra tonalidade de pele consistiria em um "desvio" da ordem natural. Consequentemente, a escravização de negros seria uma forma de regenerá-los, trazê-los para a civilização.

Somente no final do século XVIII e ao longo do século XIX começou a se difundir verdadeiramente o conceito moderno de racismo, ou seja, "a ideia de uma diferença essencial, inscrita na própria natureza dos grupos humanos, em suas características físicas", , dando, com isso, o primeiro passo em direção ao chamado racismo científico.

Arthur de Gobineau (1816-1882) figurou como um dos principais expoentes do período, afirmando que um dilúvio nos primórdios da humanidade propiciou o aparecimento de três raças distintas, sendo o negro a de menor grau de desenvolvimento. A creditava que a civilização só poderia ser construída pela raça branca e alertava para o perigo da miscigenação que,

${ }^{7}$ HOFBAUER, Andreas. Uma história de branqueamento ou o negro em questão. São Paulo: Editora UNESP, 2006.

${ }^{8}$ Hofbauer afirma que o médico François Bernier (1625-1688) foi o primeiro pensar a dividir os seres humanos em espécies/raças. No entanto, somente a partir de Carl Lineu (1707-1778) é que tem início o período de classificações onde a cor da pele é critério fundamental. HOFBAUER, Andreas. Uma história de branqueamento ou o negro em questão. pp. 103-104.

${ }^{9}$ WIEVIORKA, Michael. O racismo, uma introdução. São Paulo: Perspectiva, 2007. p.19. 
segundo ele, levava à degeneração. Para muitos, foi o pai do racismo científico, o que chamaremos de racismo biológico como forma de diferenciar a abordagem de outras épocas. Gobineau deu notoriedade à clássica hierarquização de raças, que seria utilizada por um longo período.

No cenário nacional, "o racismo surge [...] na cena política brasileira como doutrina científica, quando se avizinha à abolição da escravatura e, consequentemente, à igualdade política e formal entre todos os brasileiros, e mesmo entre os africanos escravizados". ${ }^{10}$

Com isso, houve uma preocupação por parte da elite na manutenção de sua posição privilegiada, de tal modo que surge a necessidade de criar novas justificativas - que não mais o escravismo - para manter o negro "em seu lugar".

\subsection{Evolucionismo e Darwinismo Social}

Desde o princípio do séc. XIX pôde-se identificar no Brasil alguns discursos que iam de encontro ao sistema escravista. Contudo, as razões lançadas a favor do encerramento do regime jamais estiveram calcados em um discurso de igualdade. Os argumentos sempre giraram em torno da "insegurança social" gerada pela tensão entre população escrava versus população livre e, principalmente, da necessidade de uma homogeneidade como povo, aqui tida como um "melhoramento racial" a partir do "cruzamento interracial" (imigração europeia), tendo como objetivo precípuo uma maior produtividade econômica.

Reforçados teoricamente com as ideias do racismo biológico e incentivados por um interesse econômico, tais argumentos acabaram incutidos no discurso social, culminando na criação de um ideário de "branqueamento",

\footnotetext{
${ }^{10}$ GUIMARAES, Antonio Sergio Alfredo. Preconceito de cor e racismo no Brasil. Rev. Antropol. vol.47 no.1 São Paulo, 2004. Disponível em http://www.scielo.br/scielo.php? script=sci_arttext\&pid=S003477012004000100001\&lang=pt, Acesso em 13 abr. 2012.
} 
ou seja, a possibilidade de ascender socialmente e de abandonar o estigma de 'negro' ou 'preto'11. Graças à escravidão no Brasil, que como todo sistema escravocrata foi marcada por um sistema de relações sociais que formava uma estrutura de domínio construída a partir de laços de lealdade e de pertencimento, os "limites entre as cores eram negociados nas relações de $\operatorname{poder}^{12 \%}$.

Esse ideário transformou-se, por um longo período, no discurso oficial do país.

Ainda que não apontasse para o "branqueamento" como a solução do país, Raimundo Nina Rodrigues (1862-1906) despontou nesse cenário como principal ícone no cientificismo racialista pátrio.

A abolição da escravidão trouxe a possibilidade de uma igualdade, ao menos formal, entre brancos e negros, e, nesse quesito, Nina Rodrigues despontou como uma das grandes vozes dissonantes.

Rodrigues reproduzia a ideia de hierarquização de raças e sustentava a teoria de diferentes níveis de evolução dos povos, consolidando no Brasil a dicotomia "raça superior/raça inferior", onde os negros e indígenas constituíam os grau menos avançados na escala evolutiva. Consequente, apontava como uma impossibilidade biológica a existência de uma relação de igualdade dentro da sociedade brasileira e concluía quanto a nossa impossibilidade como povo. ${ }^{13}$

O médico alertava para o perigo da degeneração do mestiço, mas, ao contrário de outros autores da época, rejeitava a possibilidade de uma homogeneização da população. A depender do grau de mestiçagem, o

\footnotetext{
${ }^{11}$ Hofbauer chama atenção para análise feita pela historiadora Hebe Maria Mattos em processos nas províncias de MG, SP e RJ onde não há qualquer menção a "negro livre" ou "preto livre". O termo "branco" é utilizado para aqueles nascidos livres e "homem livre" para os descendentes de africanos que conquistaram sua liberdade. HOFBAUER, Andreas. Uma história de branqueamento ou o negro em questão. p. 177.

${ }^{12}$ HOFBAUER, Andreas. Uma história de branqueamento ou o negro em questão. p. 174.

${ }^{13}$ AUGUSTO, Cristiane Brandão. \& ORTEGA, Francisco. Nina Rodrigues e a patologização do crime no Brasil.
} 
indivíduo era "inteiramente inaproveitável e degenerado" ou "válido e capaz de superior manifestação da atividade mental", rotulação que influía em seu grau de responsabilidade penal ${ }^{14}$.

Um de seus grandes postulados era o tratamento individual para cada criminoso, dependendo de seu "desenvolvimento racial".

As premissas do estudo de Nina Rodrigues (1894) foram resumidas por ele da seguinte forma: (1) a cada fase da evolução da humanidade, se comparam raças antropologicamente distintas, corresponde uma criminalidade própria, compatível com o grau do seu desenvolvimento intelectual e moral; (2) existe uma impossibilidade material, orgânica, de os representantes das fases inferiores da evolução social passarem bruscamente, em uma só geração, sem transição lenta e gradual, ao grau de cultura mental e social das fases superiores; (3) perante as conclusões tanto da sociologia como da psicologia moderna o postulado da vontade livre ${ }^{15}$ como base da responsabilidade penal só se pode discutir, sem flagrante absurdo, quando for aplicável a uma agremiação social muito homogênea, que esteja num mesmo grau de cultura mental média. ${ }^{16}$

Apesar de fazer amplo uso do termo "raça", Rodrigues nunca definiu o que seria esse aspecto que tanto influenciava na "evolução" dos seres humanos.

Em caminho oposto, encontrava-se o também médico Manoel Bomfim (1868-1932). Bomfim renegava a teoria da inferioridade racial dos latino americanos como causa do "atraso" em relação aos europeus e apontava como verdadeira razão a situação de "organismo parasitado" em que viveu a América Latina durante séculos ao ter seus recursos extraídos indiscriminadamente pelos países ibéricos. Compreendia que a América Latina "era um produto

\footnotetext{
${ }^{14}$ Conceitos retirados de RODRIGUES, Raimundo Nina. As raças humanas e a responsabilidade penal no Brazil apudAUGUSTO, Cristiane Brandão.\&ORTEGA, Francisco. Nina Rodrigues e a patologização do crime no Brasil. Disponível em $<$ http://www.scielo.br/scielo.php?pid=S180824322011000100011\&script=sci_arttext>. p.

${ }^{15}$ Trata-se do chamado livre arbítrio, onde considera-se que o homem nasce livre para optar por suas ações e tem capacidade de autodeterminação. É o que hoje define a culpabilidade do agente.

${ }^{16}$ AUGUSTO, Cristiane Brandão. \&ORTEGA, Francisco. Nina Rodrigues e a patologização do crime no Brasil. Rev. Direito GV vol.7 no.1 São Paulo Jan./June 2011. Disponível em $<$ http://www.scielo.br/scielo.php?pid=S180824322011000100011\&script=sci_arttext $>$.
} 
histórico que engendrava um duplo sistema espoliativo: o externo (colonialista) e o interno (classista) ${ }^{\prime 17}$.

Bomfim fazia questão de ressaltar que a herança cultural não era reduzida à herança racial, refutando a teoria de $\operatorname{Ribot}^{18}$ sobre a transmissão hereditária do "caráter nacional".

Era grande crítico do conservadorismo da classe dominante que, para ele, seria causado parte pela educação bacharelesca, parte pelo sistema político-econômico (capitalismo). Inferiu disso - do conservadorismo -, dentre outras coisas, a causa da manutenção do Brasil como um país agrícola desde os tempos de colônia ${ }^{19}$.

Bomfim já refutava ideias elitistas ancoradas no racismo, discordando, não apenas da degenerência do mestiço que, para ele não possuía "nenhuma modificação orgânica particular que possa ser considerada uma regressão ancestral” ${ }^{20}$, mas da teoria da superioridade racial como um todo, sustentando não passar "de um sofismo do egoísmo humano, hipocritamente mascarado de ciência barata, e covardemente aplicada à exploração dos fracos pelos fortes"21.

Apontava como uma grande contradição da teoria da superioridade racial o fato de, na própria Europa, os povos lutarem entre si. Dizia que havia uma confusão entre as "alternativas histórias dos povos com a inferioridade definitiva das raças",22.

\footnotetext{
${ }^{17}$ ALVES FILHO, Aluizio. Manoel Bomfim - combate ao racismo, educação popular e democracia radical. São Paulo: Editora Expressão Popular, 2008.

${ }^{18}$ Psicólogo francês (1839-1916), formado em Filosofia, responsável pela introdução da psicologia experimental em França. Interessou-se também pela psicologia clínica colaborando com psiquiatras com o objetivo de relacionar as doenças mentais com as suas bases orgânicas.

${ }^{19}$ Bonfim afirmava ser o fazendeiro um parasita que, se não mais poderia parasitar o escravo, parasitaria o Estado.

${ }^{20}$ BOMFIM, Manoel. América Latina: males de origem. Centro Edelstein de Pesquisas Sociais. Rio de Janeiro, $2008 . \quad$ Disponível em $<\mathrm{http}: / /$ www.do.ufgd.edu.br/MarioJunior/arquivos/BOMFIM_A_America_Latina_Males_de_origem.p df>. Acesso em 05 mai. 2012. p. 208.

${ }^{21}$ Ibid. p. 190.

${ }^{22}$ Ibid. p. 200.
} 


\subsection{Democracia Racial}

Ainda na primeira década do séc. XX as condições políticas começaram a favorecera construção da teoria de maior aceitação na evolução do pensamento racial brasileiro. A decisão em participar da I Grande Guerra trouxe a necessidade de provocar um movimento nacionalista no país.

As diferenças fenotípicas encontradas na constituição do povo brasileiro, até então vistas como um empecilho para o sucesso econômico do país, passaram a ser valorizadas. Iniciou-se a busca por uma "solução caseira" para a evolução da nação e o mestiço não mais foi apresentado como o vilão.

No viés teórico, podemos apontar para duas vertentes relevantes: a) a "genetização" do conceito de raça, ou seja, sua definição derivaria de uma análise do material genético do indivíduo e b) o entendimento desenvolvido por Franz Boas quanto a existência de uma diferenciação entre os efeitos genéticos e os efeitos culturais que caracterizam o comportamento humano ${ }^{23}$, ou seja, não existiria uma hierarquização de raças e culturas, apenas características distintas ${ }^{24}$. Ambas as vertentes ganharam maior notoriedade ao comporem uma crítica feroz aos movimentos fascistas crescentes na Europa na década de 1930.

Com a mesma proposta de diferenciar cultura e raça, Arthur Ramos foi o principal nome dentre aqueles que utilizaram como base o estudo de Nina Rodrigues para analisar questões raciais no Brasil.

Entretanto, Ramos não limitou-se a reproduzir os pressupostos teóricos de seu antecessor. Ao contrário, ampliou e reviu dados etnográficos colhidos na pesquisa de campo e, também, acresceu materiais.

\footnotetext{
${ }^{23}$ Segundo HOFBAUER, Andreas. Uma história de branqueamento ou o negro em questão. p. 216, "a palavra 'racismo' surge exatamente nesse momento".

${ }^{24} \mathrm{Em}$ uma tradução livre, Boas dizia que "cultura é o resultado da interação de um sem número de fatores e não há evidência de que as diferenças existentes entre raças humanas, particularmente entre não integrantes da raça Branca, tem qualquer influência direta sobre a evolução cultural". (Apud HOFBAUER, Andreas. Uma história de branqueamento ou o negro em questão. pp. 245-246. Nota 36)
} 
Sem a pretensão em identificar "raças puras", Ramos defendia que as diferenças existentes não eram raciais e sim culturais, estabelecendo aí sua maior crítica à teoria de Rodrigues No total, Ramos aponta "três postulados falsos" em Nina Rodrigues: a) a tese das desigualdades raciais; b) a tese da inferioridade e da degenerescência do mestiço brasileiro; c) a tese da responsabilidade atenuada dos negros, índios e mestiços brasileiros, decorrente dos dois postulados iniciais. ${ }^{25}$

Ramos procurou não fazer uso da noção de "raça" mas, assim como Freyre fez em um momento posterior, fracassou. Isto porque, para estabelecer o nível cultural do indivíduo, analisava as suas características físicas (fenotípicas).

A essa percepção, podemos acrescentar duas outras. Primeiro, do mesmo modo que não seria possível separar "raças puras" ${ }^{26}$ umas das outras, também parece impossível delimitar com precisão "culturas distintas". Segundo, quaisquer que sejam os critérios utilizados para a delimitação dessas diferenças culturais, é passível de crítica a idéia de que há culturas "superiores" ou mais "adiantadas" do que outras. ${ }^{27}$

Com as bases teóricas e sociais estabelecidas, Gilberto Freyre, utilizando-se do critério de Boas como marco teórico, introduziu um conceito de convivência racialmente pacífica no Brasil.

Visando explicar a formação do povo brasileiro, Freyre atribuiu à composição mista na ascendência portuguesa a sua propensão de

\footnotetext{
${ }^{25}$ GUTMAN, Guilherme. Raça e psicanálise no Brasil. O ponto de origem: Arthur Ramos. Rev. latinoam. psicopatol. fundam. vol.10 no.4 São Paulo Dec. 2007. Disponível em http://www.scielo.br/scielo.php?pid=S1415-47142007000400014\&script=sci_arttext . Acesso em 29 mar. 2012.

${ }^{26}$ Sobre isso, escreve Ramos: "Quando falamos de 'contatos de raça', pressupomos a existência de raças puras, ou de indivíduos representantes de stocks raciais puros ou relativamente puros, isto é, sem mestiçagem, que se puseram em contato biológico com outros indivíduos representantes de outros stocks raciais também puros ou relativamente puros. Mas aqui nos defrontamos com uma dificuldade insuperável: é que não encontramos hoje na face da terra stocks puros, sem cruzamentos com outros, imunes de todo contato". RAMOS Arthur. Primitivo e loucura, Salvador, Imprensa Oficial do Estado, 1926. pp. 199-200 apud GUTMAN, Guilherme. Raça e psicanálise no Brasil.

${ }^{27}$ GUTMAN, Guilherme. Raça e psicanálise no Brasil. O ponto de origem: Arthur Ramos. Rev. latinoam. psicopatol. fundam. vol.10 no.4 São Paulo Dec. 2007. Disponível em http://www.scielo.br/scielo.php?pid=S1415-47142007000400014\&script=sci_arttext . Acesso em 29 mar. 2012.
} 
"miscibilidade" com outras raças, no Brasil, caracterizada pela integração entre a casa grande e a senzala. Defendia que, apesar da repulsa causada, o sistema escravocrata e a colonização latifundiária teriam sido o único meio de sustentação do país em seus primeiros séculos de existência. Segundo ele, a introdução da fé católica propiciaria a superação das diferenças raciais ${ }^{28}$.

Entretanto, Freyre não conseguiu fugir da concepção clássica. Ao utilizar conceitos como "raça superior/inferior" e "culturas adiantadas", continuou estabelecendo, a despeito das ideias defendidas por Boas, uma hierarquização de raça e cultura. Em seu trabalho, chegou a mencionar que a vinda de negros "adiantados culturalmente" beneficiou a formação do povo brasileiro.

Mesmo que Freyre não tenha cumprido completamente sua proposta metodológica de seguir Boas [...] a inspiração boasiana ajudou-o a criar uma nova imagem, uma espécie de mito de origem de uma nova nação nos trópicos [...], ele constrói os alicerces da ideia de que existe, de fato, uma "cultura brasileira", produto de um amalgamento de diferentes "raças/culturas", que constituiria a "essência de uma nova nação". [...] [O] "mestiço" aparece quase como uma prova da - postulada convivência harmoniosa entre "raças". 29

Freyre, então, solidifica um modelo de relação racial que ficará mais tarde conhecido como mito da "democracia racial".

Segundo esse mito, o país teria sido formado pela influência genética e cultural de três povos: portugueses, indígenas e negros. Esses grupos originais geraram, por causa do processo de miscigenação longo dos séculos, uma população pronunciadamente mestiça. Tal origem nos teria retirado, ou mesmo impossibilitado, formas agressivas de ódio e conflito racial. ${ }^{30}$

Importante salientar que Freyre jamais utilizou tal nomenclatura. Com o passar do tempo e uma interpretação crítica das informações trazidas por ele, foi que sua teoria ganhou essa alcunha.

\subsection{Projeto UNESCO}

\footnotetext{
${ }^{28}$ HOFBAUER, Andreas. Uma história de branqueamento ou o negro em questão. pp. 247-248.

${ }^{29}$ HOFBAUER, Andreas. Uma história de branqueamento ou o negro em questão. pp. 248-250.

${ }^{30}$ PAIXÃO, Marcelo. Manifesto Anti-Racista. p. 44.
} 
A ideia de branqueamento introduzida ainda nos tempos de escravidão apenas foi questionada no princípio dos anos de 1950. A necessidade de obter mão-de-obra para o crescente mercado capitalista e a criação de um mercado consumidor serviu de impulso para se discutir as diferenças de oportunidades que eram dadas a imigrantes e a negros. Era preciso definir a "posição dos descendentes de escravos dentro do novo modelo capitalista ${ }^{3 l}$.

No âmbito mundial, com o mundo abalado pelos efeitos devastadores no nazismo-fascismo no pós-II Grande Guerra, a UNESCO estabeleceu como meta combater políticas racialmente discriminatória se, para tanto, deveria analisar as relações raciais menos conflituosas.

Muito em função da influência de alguns cientistas da casa, tomados pela ideia da convivência sem tensões raciais, a Organização optou por escolher o Brasil como 'laboratório' de estudos. O Projeto consistiu na organização de uma série de trabalhos monográficos que deveriam abordar as relações raciais brasileiras com o intuito de promover o país como símbolo da democracia.

Os estudos de relações raciais, no Brasil, permanecerão por muitos anos, prisioneiros dessa agenda, período em que se discutirão basicamente a existência ou não do preconceito racial no Brasil e a nossa diferença específica em relação aos Estados Unidos. ${ }^{32}$

Dentre os vários trabalhos produzidos, destacaremos dois: a pesquisa realizada por Roger Bastide e Florestan Fernandes, que fazem a conexão entre preconceito racial à desigualdade econômica; e a realizada por Oracy Nogueira, ao abordar de forma mais explícita a questão do branqueamento.

Roger Bastide foi convidado para dirigir uma das pesquisas em São Paulo e insistiu em convidar Florestan Fernandes para o estudo. Definiram como orientação teórica a ideia de que o preconceito racial tende a se desenvolver quando há o contato entre pessoas de "raças" diferentes e suas

\footnotetext{
${ }^{31}$ HOFBAUER, Andreas. Uma história de branqueamento ou o negro em questão. p. 262.

${ }^{32}$ GUIMARAES, Antonio Sergio Alfredo. Preconceito de cor e racismo no Brasil. p. 18.
} 
condições de desigualdade econômica estejam definidas pelas marcas raciais ${ }^{33}$. Afirmavam que a dominação patrimonialista foi mantida mesmo após a queda da escravidão, de forma tal que o preconceito racial seria maior nas camadas mais altas da sociedade. Assumiram uma análise bastante formal sobre a realidade brasileira e atribuíram a desigualdade entre negros e brancos ao atraso causado pelo uso do sistema escravocrata por tantos anos.

$\mathrm{O}$ atraso da ordem racial ficou, assim, como um resíduo do antigo regime e só poderá ser eliminado, no futuro, pelos efeitos indiretos da normalização progressiva do estilo democrático de vida e de ordem $\operatorname{social}^{34}$.

Entretanto, essa abordagem a partir da "consciência de classe" não permitiu uma análise mais detalhada dos valores que constituíam o preconceito "e que, na prática, excluem a possibilidade de que ideários historicamente elaborados e estratégias identitárias possam ter alguma influência sobre processos de formação grupal, inclusive sobre a maneira como as pessoas percebem e lidam com as diferenças humanas" ${ }^{\prime 3}$.

Já Oracy Nogueira optou por fazer uma comparação entre Brasil e Estados Unidos a partir de suas observações em Itapetininga. Considerou como um avanço o reconhecimento da existência de preconceito racial no Brasil, que acontece pela primeira vez nos estudos patrocinados pela Unesco. Entretanto, ponderou que, dada a diferença entre as formas de externalização do preconceito no Brasil e nos EUA, não bastava apenas reconhecer a existência. Seria necessário saber se tais diferenças encontravam-se na intensidade ou de forma qualitativa ("quanto à natureza"). Defendia que as diferenças eram quanto à natureza das manifestações.

Com base nos estudos supracitados e na literatura referente à problemática racial estadunidense, Nogueira formulou o que pode-se chamar

\footnotetext{
${ }^{33}$ HOFBAUER, Andreas. Uma história de branqueamento ou o negro em questão. p. 271.

${ }^{34}$ HOFBAUER, Andreas. Uma história de branqueamento ou o negro em questão. p. 276.

${ }^{35}$ Ibid. p. 273.
} 
de "quadro de referência" para caracterizar as "situações raciais" dos Estados Unidos e do Brasil. Nogueira ressaltou que trata-se de

Conceitos ideais - no sentido de exagerações lógicas, inferidas de casos concretos, sendo que todo o caso particular propende para um ou outro dos dois pólos "ideais", embora nenhum caso coincida, ponto por ponto, com qualquer deste ${ }^{36}$.

De um modo geral, dizia que, tomando a literatura referente à "situação racial" brasileira, produzida por estudiosos ou simples observadores brasileiros e norte-americanos, notava-se que os primeiros, influenciados pela ideologia de relações raciais característica do Brasil, tendiam a negar ou a subestimar o preconceito aqui existente, enquanto os últimos, afeitos ao preconceito, tal como se apresentava em seu país, não o conseguem "ver", na modalidade que aqui se encontra. O preconceito, tal como existe no Brasil, cai abaixo do limiar de percepção de quem formou sua personalidade na atmosfera cultural dos Estados Unidos ${ }^{37}$.

Nogueira, então, definiu seus "conceitos ideais". Apresentou como preconceito de marca aquele presente no Brasil e que "se exerce em relação à aparência, isto é, quando toma por pretexto para as suas manifestações os traços físicos do indivíduo, a fisionomia, os gestos, o sotaque" ${ }^{38}$. Em contraposição, apresentou como preconceito de origem aquele existente nos EUA, "quando basta a suposição de que o indivíduo descende de certo grupo étnico para que sofra as consequências do preconceito"39.

Oracy sustenta que necessidade brasileira de miscigenação não passa de um tipo sutil de preconceito e relaciona isso ao ideário do branqueamento. "Como um dos primeiros cientistas, ele chega a caracterizar o branqueamento

\footnotetext{
${ }^{36}$ NOGUEIRA, Oracy. Preconceito racial de marca e preconceito racial de origem: sugestão de um quadro de referência para a interpretação do material sobre relações raciais no Brasil. Tempo soc. vol.19 no.1 São Paulo June 2007. Disponível em <http://www.scielo.br/scielo.php? script=sci_arttext\&pid=S010320702007000100015\&lang=pt $>$. Acesso em 06 mar. 2012.

${ }^{37}$ NOGUEIRA, Oracy. Preconceito racial de marca e preconceito racial de origem. p. 291.

${ }^{38}$ Ibid. p. 292.

${ }^{39}$ Idem.
} 
explicitamente como uma 'ideologia' e descreve sua força sociopsicológica ${ }^{40}$, como um desejo pelos traços caucasóides.

\subsection{Discussão Contemporânea}

O fim do ciclo de estudos da UNESCO trouxe como grande vitória a quebra de um discurso hegemônico pró-branqueamento. A problemática da discriminação racial retornaria ao cenário intelectual do país a partir de outra perspectiva no final da década de 1970 através de trabalhos como os de Carlos Hasenbalg.

Diferentemente de Fernandes, Hasenbalg alertava que a presença do preconceito na sociedade urbana moderna não seria como mera herança do antigo regime. Para ele, "a sociedade capitalista conferiu uma nova função ao preconceito e às discriminações raciais ${ }^{41}$ ".

Tais funções eram calcadas em dois pontos: a) a discriminação e preconceitos raciais não são mantidos intactos após a abolição, mas pelo contrário, adquirem novos significados e funções dentro das novas estruturas, e b) as práticas racistas do grupo dominante branco que perpetuam a subordinação dos negros não são meros arcaísmos do passado, mas estão funcionalmente relacionados aos benefícios materiais e simbólicos que o grupo branco obtém da desqualificação competitiva dos não-brancos ${ }^{42}$.

Dessa forma, não apenas concluímos o estudo das relações raciais, como chegamos ao patamar atual de discussão, onde o racismo é tido como um problema quase crônico dentro da sociedade. É preciso, então, pensar formas de combatê-lo. Além das medidas afirmativas estabelecidas pelo Poder Executivo, principalmente a partir da Carta Magna de 1988, encontramos medidas coercitivas existentes desde os anos 1950.

\footnotetext{
${ }^{40}$ HOFBAUER, Andreas. Uma história de branqueamento ou o negro em questão. p. 277.

${ }^{41}$ HOFBAUER, Andreas. Uma história de branqueamento ou o negro em questão. p. 279.

${ }^{42}$ HASELBALG, Carlos A. Entre o mito e os fatos: racismo e relações raciais no Brasil. Dados, Rio de Janeiro, v. 38, no 2, 1995.p. 85 apud HOFBAUER, Andreas. Uma história de branqueamento ou o negro em questão. p. 279.
} 
Nesse viés, enxergamos o Poder Legislativo como ferramenta indispensável na elaboração de leis que contribuam, também, no combate do racismo. 


\section{Legislação Penal Brasileira Antidiscriminação}

Ao pensarmos no Poder Legislativo, nos vem a mente sua definição como o órgão do qual se vale o Estado para, como função típica, legislar e exercer a fiscalização contábil, financeira e orçamentária do Executivo. No entanto, com freqüência nos esquecemos de pensar o Poder Legislativo a partir das pessoas que o exercem. Pessoas que são influenciáveis e suscetíveis a mudanças em seu meio.

Quando utilizamos a Teoria Crítica da Raça (TCR), teoria desenvolvida nos Estados Unidos da América no contexto da luta pelos direitos civis dos negros e nosso marco teórico ao longo do trabalho, conseguimos extrair premissas que fortalecem a nossa percepção da relevância dos atores legislativos.

Em uma tradução livre de Harris, a Teoria Crítica da Raça

deriva do reconhecimento de que o direito não reflete a raça como um mero fenômeno externo; o direito e as doutrinas legais constituem uma narrativa ideológica sobre o que são raça e racismo. [...] O direito produz, constrói e constitui a raça, não apenas nas esferas onde a raça é explicitamente articulada, mas também onde a raça não é mencionada ou reconhecida ${ }^{43}$.

Em última análise, Harris diz que essa teoria busca "expor o papel do Direito em manter e legitimar o injusto status quo" 44 .

Consequentemente, a própria legislação traz em seu teor, traços do que ocorre na sociedade que lhe gestou. Com o objetivo de esclarecer as razões para a criação das leis que pontuaremos, nos propomos a conectar os marcos legislativos aos teórico-ideológicos explicitados no capítulo anterior.

\subsection{A histórica criminalização do negro}

\footnotetext{
${ }^{43}$ HARRIS, Cheryl I. Critical Race Studies: An Introduction. In UCLA Law Review, 49. Junho 2002.

${ }^{44}$ Idem.
} 
No Brasil o Direito não assumiu um papel distinto ao estabelecido por Harris. O que podemos observar de forma muito clara é que, ao longo de toda a história legislativa brasileira,

a função da lei, especialmente da lei penal, e também do Poder Judiciário, foi basicamente legitimar e institucionalizar os interesses brancos brasileiros, ao mesmo tempo em que servia de instrumento de controle sobre o corpo e a mente da população negra brasileira. ${ }^{45}$

Desde as Ordenações Filipinas, vigentes até 1824, o escravo era equiparado às coisas e animais, não possuindo qualquer direito para efeitos civis, mas plenamente capaz de ser responsabilizado penalmente. Nas mesmas Ordenações, inserido no Livro V, com uma clara contextualização religiosa típica de seu tempo, era declarado obrigatório o batismo do escravo, assim como já encontrávamos o cerceamento cultural através da proibição dos bailes de escravo.

Na seara constitucional, a Carta Magna de 1824 veio encerrar a vigência das Ordenações Filipinas no Brasil e declarou a igualdade de todos perante a lei - que se restringirá à igualdade formal -, trazendo a baila também a necessidade de uma maior repressão da criminalidade, abrindo espaço para o Código Criminal do Império de $1830^{46}$.

"Saudado como símbolo de modernidade e portador de novas ideias liberais então em voga na Europa ${ }^{47}$,, o Código de 1830 não trouxe qualquer avanço para a cidadania do escravo. Ao contrário, demonstrou grande preocupação em controlar a rebeldia negra, escrava ou liberta. Para isso, entre outras medidas, fixou a maioridade penal em 14 anos, criou o crime de

\footnotetext{
${ }^{45}$ SILVA JÚNIOR, Hédio. Do racismo legal ao princípio da ação afirmativa: a lei como obstáculo e como instrumento dos direitos e interesses do povo negro. In: GUIMARÃES, Antônio Sérgio A.; HUNTLEY, Lynn. Tirando a máscara: ensaio sobre o racismo no Brasil. São Paulo: Paz e Terra, 2000. Pág. 360

${ }^{46}$ Hédio observa que a Constituição de 1824 ainda previu a criação de um Código Civil "o quanto antes". No entanto, este só foi promulgado quase cem anos depois - 1916 - enquanto o Código Criminal foi preparado em seis anos apenas.

${ }^{47}$ SILVA JÚNIOR, Hédio. Do racismo legal ao princípio da ação afirmativa. p. 361.
} 
insurreição, punia a celebração religiosa que não fosse a oficial ${ }^{48}$, criou o crime de vadiagem e criminalizou a mendicância. ${ }^{49}$

A transição para o Código Penal posterior em 1890, apesar das turbulências políticas, como a Lei Áurea e Proclamação da República, apenas apresentou um enrijecimento na repressão dos negros. Além da diminuição da maioridade penal para nove anos, houve a criminalização da capoeira, do chamado "espiritismo", que abrangia as manifestações religiosas negras e a manteve-se da criminalização da vadiagem e da mendicância.

Satisfeito com o "progresso" alcançado pelo Código de 1890, Nina Rodrigues afirmou que

[...] no Brazil, por causa das suas raças selvagens e barbaras, o limite de quatorze annos ainda era pequeno! [...] o menino negro é precoce, $[. .$.$] ; muitas vezes excede o$ menino branco da mesma idade; mas cedo seus progressos param; o fructo precoce aborta [...] quanto mais baixa fôr a idade em que a acção da Justiça, ou melhor, do Estado se puder exercer sobre os menores, maiores probabilidades de exito terá ella $[\ldots]^{50}$

As Constituições de 1891 e 1934 persistiram em declarar uma igualdade formal, com a grande contradição de prescreverem em seus textos, restrições étnicas na escolha dos imigrantes e preverem uma "educação eugênica", em consonância com as ideia eugenistas em voga à época. Manoel Bonfim desferiu sérias críticas a Carta de 1891, acusando ser uma falácia o sufrágio universal e a democracia por ela trazidas, quando os analfabetos não podiam votar e eles representavam $90 \%$ (noventa por cento) da população brasileira ${ }^{51}$.

\footnotetext{
${ }^{48}$ Católica Apostólica Romana, de acordo com a Constituição de 1824.

${ }^{49}$ Basileu Garcia (apud Silva Júnior), ao comentar sobre a regulamentação da pena de morte ocorrida em 1835 explica que "nas porfias parlamentares sobre o extremo suplício, o grupo conservador propugnava-lhe a admissão no código; outro grupo, dos liberais, se opunha. Venceram os conservadores por pequena maioria. $\mathrm{O}$ seu argumento principal era a criminalidade do elemento servil, muito difundida. Entendiam que, sem a aludida pena, não se manteria a ordem entre os escravos, os quais, pelo seu teor de existência, seriam indiferentes a outros castigos."

${ }^{50}$ RODRIGUES, Nina. As raças humanas e a responsabilidade penal no Brazil. Editora Guanabara, 1894. p. 179 apud SILVA JÚNIOR, Hédio. Do racismo legal ao princípio da ação afirmativa. p. 364.

${ }^{51}$ ALVES FILHO, Aluizio. Manoel Bomfim - combate ao racismo, educação popular e democracia radical. p. 24.
} 
Vale ressaltar que enquanto a Carta de 1934 repudiava expressamente a discriminação racial (Art. 113. "Não haverá privilégios, nem distincções, por motivo de nascimento, sexo, raça...”), as Cartas de 1937 e 1946, voltaram a declarar apenas a igualdade de todos perante a lei.

Somente em 1951 houve, pela primeira vez, uma mobilização para a criação de uma lei infraconstitucional como mecanismo jurídico-penal antidiscriminatório.

\subsection{Lei Afonso Arinos}

Conforme já visto, a década de 1950 foi marcada, no âmbito racial, pelos estudos patrocinados pela UNESCO e que trouxeram como grande marco o reconhecimento da existência de preconceito no Brasil, iniciando a quebra do conceito de uma "democracia racial" e a convivência pacífica, apesar de desigual, entre as "raças" componentes do povo brasileiro.

Nesse cenário foi proporcionada politicamente a oportunidade de se editar a primeira lei que considerasse como ilícito penal a discriminação. Entretanto, para se entender como foi possível alcançar a Lei Afonso Arinos, faz-se imperioso mencionar a militância negra e sua participação nos eventos que antecederam a promulgação da legislação.

A organização do movimento negro - que, ao contrário do que é dito, possui registros desde antes da década de 20, com o surgimento de uma imprensa negra bastante ativa ${ }^{52}$ - teve um papel primordial em todas as conquistas relacionadas a promulgação de normas que combatessem e objetivassem, de qualquer maneira, a desigualdade racial instaurada no país.

\footnotetext{
${ }^{52}$ NASCIMENTO, Abdias \& NASCIMENTO, Elisa Larkin. Reflexões sobre o Movimento Negro no Brasil, 1938-1997.In. GUIMARÃES, Antonio Sérgio Alfredo \& HUNTLEY, Lynn. (Orgs.) Tirando a Máscara: Ensaios sobre o Racismo no Brasil. São Paulo. Paz e Terra/SEF. 2000. p. 204.
} 
Um dos pilares de toda a luta para a diminuição dessa desigualdade sempre foi a necessidade de por um fim à discriminação racial que exclui o negro.

Alguns marcos podem ser apontados ao longo da história legislativa brasileira. Nos anos de 1945 e 1946 foram realizadas, organizadas pelo Teatro Experimental Negro, expoente do movimento negro, reuniões da chamada Convenção Nacional do Negro Brasileiro em São Paulo e Rio de Janeiro respectivamente. Após deliberações, foi lançado o Manifesto à Nação Brasileira que trazia como reivindicação, entre outras, a promulgação de normas antidiscriminatórias com medidas punitivas concretas.

Entretanto, apesar da boa repercussão do Manifesto no meio partidário e surgida a oportunidade para que o tema fosse discutido na Assembleia Nacional Constituinte de 1946, com argumentos de que uma lei nesse sentido acabaria por "restringir o sentido mais amplo da democracia" e de que "faltaria exemplos concretos" para fundamentá- $\mathrm{la}^{53}$, a proposição foi retirada da pauta de deliberações, tornando-se vítima do 'mito da democracia racial brasileira'.

Somente após uma sequência de casos de discriminação ocorridos contra artistas negros, inclusive estadunidenses, entre 1947 e 1950, foi que a possibilidade de criminalização da prática discriminatória voltou a ser debatida, culminando com a Lei 1.390/51, chamada Lei Afonso Arinos.

Em um primeiro momento, a Lei poderia ser considerada uma verdadeira conquista do movimento negro. No entanto, a previsão se suas condutas como meras contravenções penais, a cominação de penas simbólicas e a própria falta de cláusulas impositivas (um artigo seria mera variação de outro), acabaram tornando a lei inócua. A própria forma como a lei foi redigida ajudou na proclamação oficial da 'democracia racial' brasileira. Um aspecto importante de sua natureza domesticadora se constitui no fato de que tem sido caracterizada como benevolente concessão de legisladores brancos, isto é, da

\footnotetext{
${ }^{53}$ Argumentos citados em ibid., p. 212.
} 
estrutura dominante, e não como fruto de uma luta e uma reivindicação do povo negro organizado politicamente. ${ }^{54}$

Apesar das severas críticas, é inegável que a Lei Afonso Arinos constituiu, não apenas um marco na luta contra a discriminação, mas uma das bases para a maior conquista até hoje para os afro-brasileiros e as chamadas minorias étnicas em geral: a promulgação da Constituição de 1988 e a valoração positiva da pluralidade étnico-cultural brasileira.

\subsection{Carta Magna de 1988}

$\mathrm{O}$ aspecto mais importante na luta contra a discriminação presente na Lei Maior de 1988 encontra-se em seu "inédito reconhecimento da relevância social deste problema ${ }^{55, "}$. Com isso, pelo menos no plano formal e no aspecto da discriminação racial, conseguimos avançar no que tange ao abandono da “perspectiva que entendia as relações raciais no Brasil como harmônicas e os problemas sociais dos negros como inexistentes ${ }^{56}$,

Através de seu artigo $5^{\circ}$, a Constituição elevou em importância direitos e garantias que por muito tempo foram negados a uma boa parcela de brasileiros. Segundo Pedro Lenza, “direitos são bens e vantagens prescritos na norma constitucional, enquanto as garantias são os instrumentos através dos quais se assegura o exercício dos aludidos direitos ${ }^{57} \%$. A principal conquista penal no âmbito nas relações raciais foi a introdução do artigo $5^{\circ}$, XLII que considerou o racismo como crime imprescritível e inafiançável.

Além de trazer para o ordenamento jurídico brasileiro instrumentos jurídicos de proteção e defesa de interesses do negro especificamente, como o reconhecimento da propriedade à comunidades quilombolas, a Carta de 1988

\footnotetext{
${ }^{54}$ NASCIMENTO, Abdias \& NASCIMENTO, Elisa Larkin. Reflexões sobre o Movimento Negro no Brasil, 1938-1997, p. 213.

${ }^{55}$ SILVA JÚNIOR, Hédio. Do racismo legal ao princípio da ação afirmativa. p. 381.

${ }^{56}$ GUIMARAES, Antonio Sergio Alfredo. Classes, raças e democracias. São Paulo: Editora 34, 2002 apud PAIXÃO, Marcelo. Manifesto Anti-Racista, p. 46.

${ }^{57}$ LENZA, Pedro. Direito constitucional esquematizado. 13. ed. rev. atual. e ampl. São Paulo: Saraiva, 2009. p. 671
} 
"redefiniu o papel da África na concepção da nacionalidade brasileira ${ }^{58 "}$. Disposições como as que dão privilégios à países de língua portuguesa (aqui inclusos Angola, Cabo Verve, Guiné-Bissau, Moçambique e São Tomé e Príncipe) no processo de nacionalização, a proteção às manifestações populares afro-brasileiras e o ensino escolar leve em conta contribuições de diferentes culturas, demonstram o combate contra a visão eurocêntrica que foi estabelecida desde os primeiros marcos legislativos.

Surge como opção também, um viés mais afirmativo do que repressivo para se alcançar a igualdade racial. Com a criação, em 1998, do Grupo de Trabalho Interministerial de Valorização da População Negra, nasce o objetivo de esclarecer para a sociedade civil a real necessidade de se desenvolver ações afirmativas, que se concretizem como políticas públicas que procuram corrigir iniquidades produzidas pelo longo processo de desigualdades, principalmente a racial. O próprio fortalecimento do Ministério Público surge como opção de combate saindo da esfera penal e perseguindo uma linha mais negocial.

\subsection{Lei Caó}

Apesar das vantagens e avanços trazidos pela Constituição de 1988 com o combate às desigualdades através de políticas públicas, conforme dito anteriormente, tal mentalidade surge apenas em 1998. Até então, as práticas discriminatórias somente encontravam limites através de uma política repressiva.

Autorizada pelo Art. 50, inciso XLII - "a prática do racismo constitui crime inafiançável e imprescritível, sujeito à pena de reclusão, nos termos da lei;”, nasceu a Lei 7.716/89, conhecida como Lei Caó, que revogou a até então vigente (e ineficiente) Lei Afonso Arinos no que tange à discriminação racial e trouxe como objeto a ofensa à coletividade (aos negros como um todo).

\footnotetext{
${ }^{58}$ SILVA JÚNIOR, Hédio. Do racismo legal ao princípio da ação afirmativa, p. 374.
} 
Analisando a nova legislação pelo viés penal material, ela ampliou seu âmbito de incidência em relação à Lei Afonso Arinos. Uma das mudanças mais relevantes foi instituir como crime, e não mais contravenção penal, a prática de qualquer ato discriminatório. Além disso, estabelece que a prática de seus tipos penais são persequíveis por ação penal pública incondicionada.

Apesar de ter sido objeto de três normas modificadoras, inexplicavelmente minorando penas e não esclarecendo pontos duvidosos e obscuros contidos na redação original, a norma continuou sendo deficiente. Uma das maiores críticas sofridas pelo texto é a dificuldade imposta pela própria legislação de enquadrar a conduta delitiva. Mesmo sendo considerado um crime de mera conduta, ou seja, aquele que não necessita do resultado para que a conduta seja considerada típica, exige-se o elemento subjetivo, qual seja, o dolo, a intenção de discriminar, o que dificulta sobremaneira o enquadramento no tipo.

São facilmente demonstráveis as limitações da técnica da força no enfrentamento da discriminação; não apenas porque passadas quase cinco décadas da consideração da discriminação como infração penal sua ocorrência e a impunidade que a reveste permanecem intactas, mas sobretudo porque a técnica da força tende a atacar apenas o resultado (a discriminação) sem tocar nas causas (o preconceito, o estereótipo, a intolerância, o racismo). ${ }^{59}$

No entanto, ainda com as deficiências técnicas da lei, sua aplicação foi praticamente ignorada pelos tribunais, "injustamente, olvidando-se de apreciar seus aspectos positivos, como se fosse inviável sua aplicação e se tratasse de tema sem relevância. ${ }^{60}$,

\subsection{Injúria Qualificada}

A figura da injúria qualificada foi introduzida no Código Penal pela Lei 9.459/97, ficando prevista no Art. $140, \S 3^{\circ}$ com a seguinte redação “Art. 140.Injuriar alguém, ofendendo-lhe a dignidade ou o decoro: $\$ 3^{\circ} \mathrm{Se}$ a injúria

\footnotetext{
${ }^{59}$ JACCOUD, Juliana \& BEGHIN, Nathalie. Desigualdades raciais no Brasil: um balanço na intervenção governamental. Brasília: Ipea, 2002. p. 18.

${ }^{60}$ SANTOS, Christiano Jorge. Crimes de preconceito e de discriminação. 2a ed. São Paulo: Saraiva, 2010. p. 81 .
} 
consiste na utilização de elementos referentes à raça, cor, etnia, religião, origem ou condição de pessoa idosa ou portadora de deficiência".

O tipo procurou abranger expressões injuriosas, ou seja, que ferem a dignidade e o decoro, tão comuns dentro dos casos de discriminação.

Apesar de criar uma espécie de injúria muito mais grave do que aquela prevista no caput, a prática do tipo penal não se enquadra em racismo, perdendo o caráter imprescritível e inafiançável dado constitucionalmente.

Ao fim e ao cabo, o artigo acabou por esvaziar ainda mais a Lei Caó, tendo em vista que as condutas, quase que de forma automática, são enquadradas como injúria qualificada e não como racismo. 


\section{Agulha no Palheiro: A Aplicação Penal da Legislação Antidiscriminação pelo Tribunal de Justiça do Rio de Janeiro}

Dada a digressão histórica feita no primeiro capítulo e a pontuação dos marcos legislativos antidiscriminatórios no capítulo anterior, estão construídos os alicerces teóricos para adentrarmos a análise dos dados recolhidos ao longo do último ano.

Importante frisar que o questionamento que impulsionou a opção pela presente linha de pesquisa foi derivado de uma análise de dados numéricos fornecidos pelo Relatório Anual das Desigualdades Raciais no Brasil 20092010. Nesse esteio, optamos por iniciar o desenvolvimento de uma pesquisa empírica que também pudesse trazer dados concretos para futuras análises da situação racial brasileira.

Restringimos nosso exame à processos judiciais em grau recursal tendo em vista a disponibilidade maior das decisões e pelo caráter mais definitivo que possui uma apelação, por exemplo, quando comparada a uma sentença em primeira instância - que envolviam a prática de discriminação racial contra negros encontrados no Poder Judiciário Fluminense e buscamos, a partir do arcabouço teórico obtido através de análise bibliográfica, examinar se existe e de que forma o racismo estrutural/institucional expande-se para o interior de uma instituição de essencial importância dentro de um Estado Democrático de Direito como o Poder Judiciário.

\subsection{Metodologia}

A metodologia utilizada consistiu na pesquisa bibliográfica elaborada a partir da leitura de textos teóricos sobre (a) a Teoria Crítica da Raça, (b) a evolução das análises raciais no Brasil e (c) na pesquisa documental elaborada a partir do levantamento de processos através da ferramenta de busca oferecida pelo sítio eletrônico do Tribunal de Justiça do Rio de Janeiro. 
No que tange aos textos teóricos abrangendo a Teoria Crítica da Raça (TCR), a maior colaboração encontrou-se no fato de conseguirmos definir, pelo menos em parte, os objetivos da teoria e, a partir disso, criticarmos a realidade pátria. Em primeiro lugar, identificarmos o papel do Direito em manter e legitimar o injusto, de acordo com Harris. Outra importante colaboração nos foi dada por Taylor ${ }^{61}$, que alerta para duas premissas, dentre outras, que marcam a TCR: $1^{\text {a }}$ ) o racismo é um fato normal e diário na vida da sociedade, manifestado de forma sutil e acobertada, a ponto de, muitas vezes, não o reconhecermos como tal ${ }^{62}$ e $2^{a}$ ) o mito da meritocracia e da "cegueira da cor $^{63 "}$ (color blindness); ao fiarmo-nos nos critérios de mérito e na padronização, o grupo dominante pode justificar a exclusão de negros das posições de poder acreditando na neutralidade de seu comportamento.

A partir das premissas acima, podemos identificar a base para a manifestação de um racismo estrutural, aqui tido como aquele manifestado na sociedade de forma, em geral, inconsciente pelo grupo dominante (brancos) e, para os negros através de uma "vulnerabilidade como sujeitos de direitos humanos e particularmente em uma situação de diferença de poder com relação à população branca ${ }^{64,}$, uma naturalização da hierarquia racial.

Esse racismo se irradia para dentro das instituições, fazendo com que delegados, promotores e magistrados não consigam analisar de forma imparcial qualquer caso que aborde relações raciais. Em sua maioria advindos

\footnotetext{
${ }^{61}$ TAYLOR, Edward. A Primer on Critical Race Theory.The Journal of Blacks in Higher Education, No. 19.The JBHE Foundation. pp. 122-124. Spring 1998.

${ }^{62}$ Segundo Oracy Nogueira, ao identificar que preconceito no Brasil é o de marca e não o de cor como o corre nos EUA, diz que "Não obstante acobertar uma forma velada de preconceito, a ideologia brasileira de relações inter-raciais, como parte do ethos nacional, envolve uma valorização ostensiva do igualitarismo racial, constituindo um ponto de referência para a condenação pública de manifestações ostensivas e intencionais de preconceito, bem como para o protesto de elementos de cor contra as preterições de que se sentem vítima”. (NOGUEIRA, Oracy. Preconceito racial de marca e preconceito racial de origem).

${ }^{63} \mathrm{~A}$ ideia de que não há diferença de tratamento entre uma pessoa branca e negra (fenotipicamente falando) e que, ao considerarmos que o negro deve receber um tratamento diferenciado em virtude do histórico de discriminação por ele sofrido, isso geraria um "racismo às avessas".

${ }^{64}$ CIDH. Caso Simone André Diniz vs. Brasil, petição 12.001. Aprovado pelo Relatório 66/06, em $21 / 11 / 2006$
} 
do grupo dominante, estão sempre presos aos pré-conceitos (a cegueira da cor, por exemplo) que lhes são incutidos desde a infância, tornando-os incapazes de prover uma solução que quebre o paradigma. Assim, "o racismo aparece [...] como um sistema generalizado de discriminações que se alimentam ou se informam uns aos outros: existe um círculo vicioso [...] que assegura a reprodução quase automática da discriminação dos negros" ${ }^{\circ 5}$.

Através das definições, objetivos e premissas acima expostos, tornou-se possível uma análise mais crítica em relação ao próprio Direito, podendo-se perceber que a doutrina jurídica nacional não considera o fator raça em suas análises e que qualquer menção que lhe é feita, ocorre no âmbito da legislação antidiscriminação, acarretando uma confusão entre a abordagem do racismo contra negros e das demais formas de discriminação.

No intuito de compreender um pouco melhor as razões pelas quais a doutrina jurídica formou-se com esse posicionamento, fez-se imperioso pesquisar a evolução das análises raciais no Brasil, conforme fizemos no primeiro capítulo, que acabou por nos mostrar como, desde o princípio, a elite brasileira fez uso do direito como mecanismo de segregação racial, voltando aqui para o que talvez seja o princípio macro da TCR: o direito define raça e racismo.

Para o levantamento dos processos objetos da análise, foram préselecionadas 6 (seis) palavras-chave ${ }^{66}$ ("racismo", "preconceito", "injúria", “discriminação racial", "preconceito racial" e "injúria racial") que deram origem à primeira leva de acórdãos, que consistiu em 355 processos criminais e 175 processos cíveis.

O levantamento dos processos objeto da análise foi feito através da ferramenta de busca do sítio eletrônico do Tribunal de Justiça do Estado do Rio de Janeiro e, com o objetivo de aperfeiçoar a análise dos casos, elaboramos

\footnotetext{
${ }^{65}$ WIEVIORKA, Michael. $O$ racismo, uma introdução. p. 30.

${ }^{66}$ As palavras-chaves aqui utilizadas são as mesmas relacionadas por Marcelo Paixão em seu Relatório Anual das Desigualdades Raciais.
} 
seis questões que deveriam ser respondidas em cada processo: I) Qual o tempo total de tramitação do processo até o julgamento em $2^{\mathrm{a}}$ instância?; II) Qual o tipo de defesa utilizada pelo autor: advocacia privada, advocacia popular ou Defensoria Pública?; III) Nos casos em que o réu era branco, como a conduta foi tipificada?;IV) Dos casos que o réu era negro, como foi tipificada?; V) Foi aplicada a agravante genérica do art. 61, II, “a” do Código Penal? e; VI) Quem ganhou a ação?.

A partir de então, foi feita uma triagem através da leitura de cada acórdão, tendo em vista que muitos processos possuíam uma das palavraschave, mas não eram utilizadas no contexto de discriminação racial contra negros e passamos às respostas das seis questões elaboradas.

\subsection{Apresentação e análise dos dados}

Os processos analisados foram categorizados conforme o uso da palavra-chave em sua ementa ou conforme a tese usada pelo(a) autor(a)/defesa. Por exemplo, em alguns processos, a palavra-chave "racismo" foi utilizada pelo(a) magistrado(a) como alusão ao artigo $5^{\circ}$, XLII da Carta Magna que trata da imprescritibilidade do crime de racismo e desenvolve argumentação tendo como fim conceder ou não a liberdade provisória de determinado réu. Essa categoria ganhou o nome de "Concessão de LP". Em outros processos, foi alegado por uma das partes que a razão do litígio é em função da avançada idade do autor(a)/ofendido(a). Então foi criada a categoria "Idosos".

A exceção feita foi quanto aos processos selecionados a partir da palavra-chave "injúria". Tendo em vista que 'injúria' é termo amplo, dificulta

uma precisa categorização. Dessa forma, nessa categoria, somente foram contabilizados e categorizados os processos que envolvem problemáticas raciais (negro).

Ressalte-se que, de acordo com a demanda, foram criadas categorias diferentes dentre os processos criminais e cíveis, havendo uma tentativa de 
manter certa uniformidade. Após o gráfico há uma legenda esclarecendo cada categoria criada.

\section{Processos Criminais}

Total de processos pesquisados: 370

Total de processos pesquisados sem duplicidades: 355

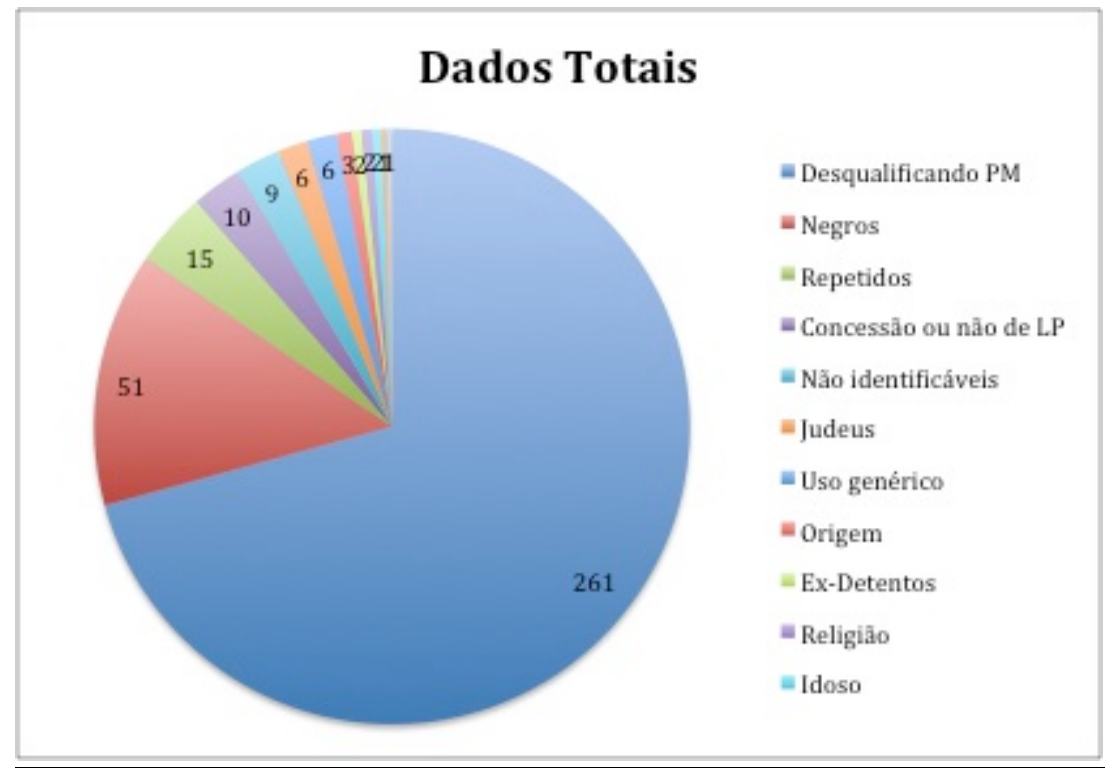

Tendo em vista a quantidade excessiva de casos que chamamos de "Desqualificando PM" (ver legenda abaixo), decidimos excluí-los da contagem e construir outro gráfico de forma que ficasse mais clara a ocorrência de processos abordando racismo contra negros.

Dados sem a contabilização dos processos que desqualificam o depoimento de PM: 


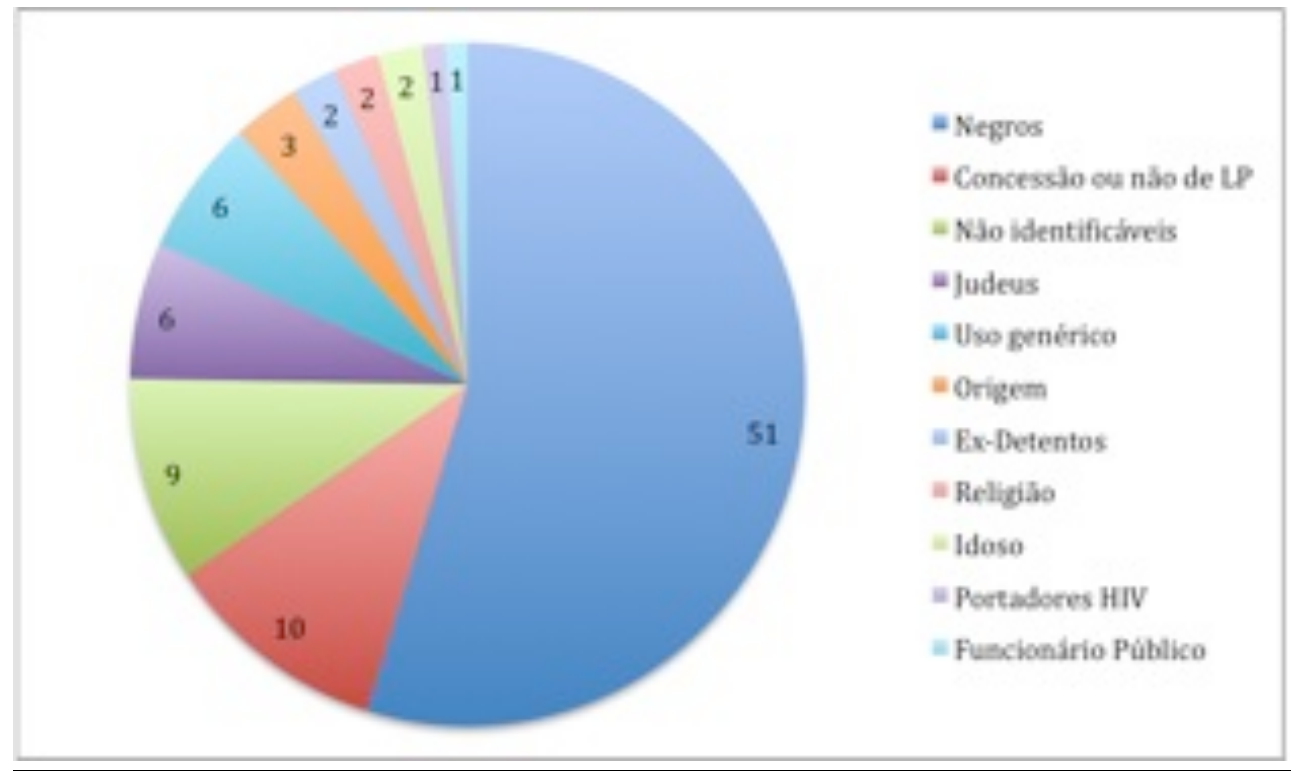

\section{Legenda:}

“Desqualificando PM": A partir de uma tentativa da defesa em desqualificar o depoimento do policial envolvido na prisão em flagrante, magistrado(a) considera válido tal depoimento. (Trecho exemplificativo extraído de um dos acórdãos: "O depoimento de policial sobre o fato de que tem ciência em razão do seu dever de oficio é válido como qualquer outro, podendo servir de base para uma sentença condenatória, mormente quando a defesa não apresenta qualquer prova conclusiva que pudesse torná-lo suspeito, não merecendo sofrer preconceito crítico pela simples condição do cargo que ocupa, não parecendo crivel que aquele que recebe do Estado para garantir a ordem pública não mereça credibilidade quando é chamado a juízo para prestar contas do seu serviço.”)

“Negros": Processos envolvendo qualquer tipo de discriminação contra negros.

"Repetidos": Considerados aqui os processos que, por ventura, apareceram como resultado de pesquisa em mais de uma palavra-chave.

“Concessão ou não de LP": Quando a palavra-chave é utilizada pelo(a) magistrado(a) como alusão ao artigo $5^{\circ}$, XLII da Carta Magna que trata da imprescritibilidade do crime de racismo e desenvolve argumentação tendo como fim conceder ou não a liberdade provisória de determinado réu.

"Não identificáveis": Considerados aqui os processos que apareceram como resultado em uma das palavraschave, mas não foi possível identificar pelo acórdão qual tipo de discriminação ocorreu.

“Judeus”: Processos envolvendo qualquer tipo de discriminação contra Judeus.

“Uso Genérico": Quando a palavra-chave foi usada no sentido popular ou de forma atécnica. Por exemplo, "tais fatos devem ser analisados sem preconceito" ou "o dano moral deve ser aplicado sem preconceito".

“Origem”: Processos envolvendo discriminação pela origem do indivíduo: oriental, indígena, nordestina etc.

“Ex-detentos": Processos abordando discriminação contra ex-detentos.

“Religião": Processos abordando discriminação contra formas de religião.

“Idosos": Processos abordando discriminação contra idosos.

“Portadores de HIV”: Processos abordando discriminação contra portadores do vírus HIV.

“Funcionários Públicos”: Processos abordando discriminação contra funcionários públicos ou equiparados. 
Com o intuito de visualizar a frequência de ajuizamentos dos processos objetos da análise e considerando mudanças legislativas que serão explicitadas mais adiante, entabulamos a quantidade de processos por cada ano, desde 1989, ano em que a Lei Caó entrou em vigor.

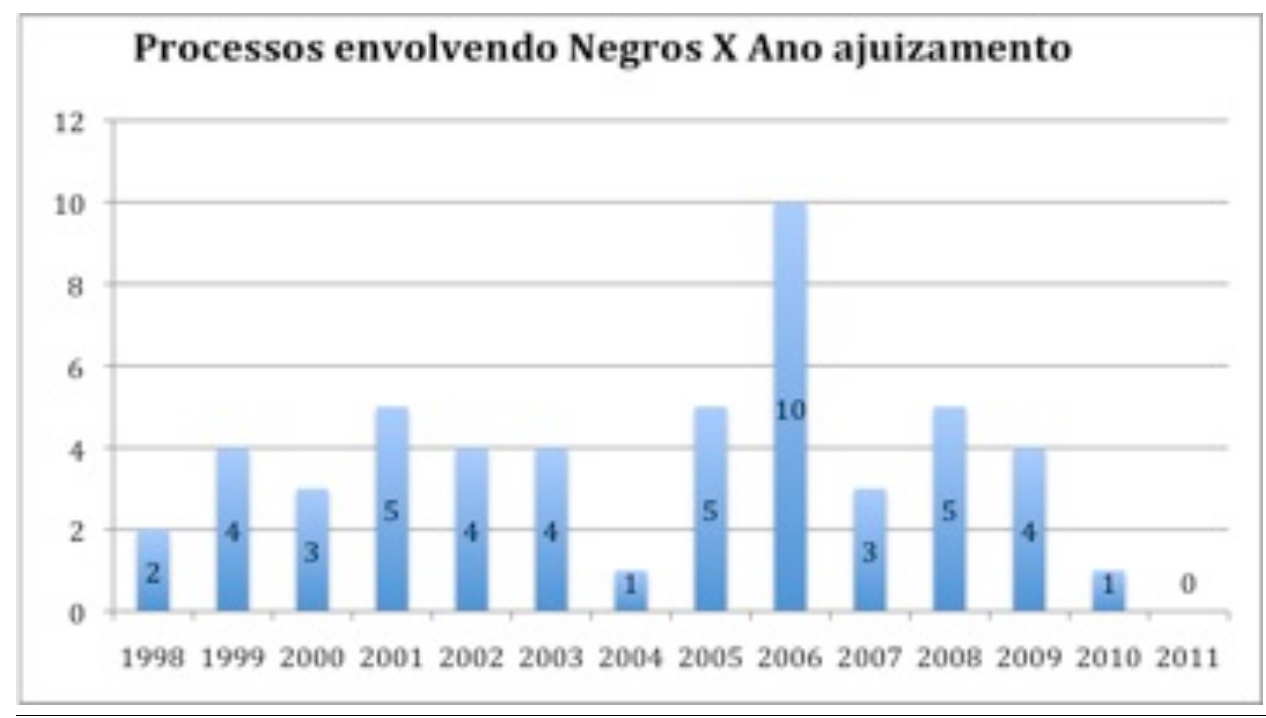

Obs: Entre os anos de 1989 e 1997 não há registros de processos envolvendo discriminação contra negros

\section{Processos Cíveis}

Total de processos pesquisados: 210

Total de processos pesquisados sem duplicidades: 175

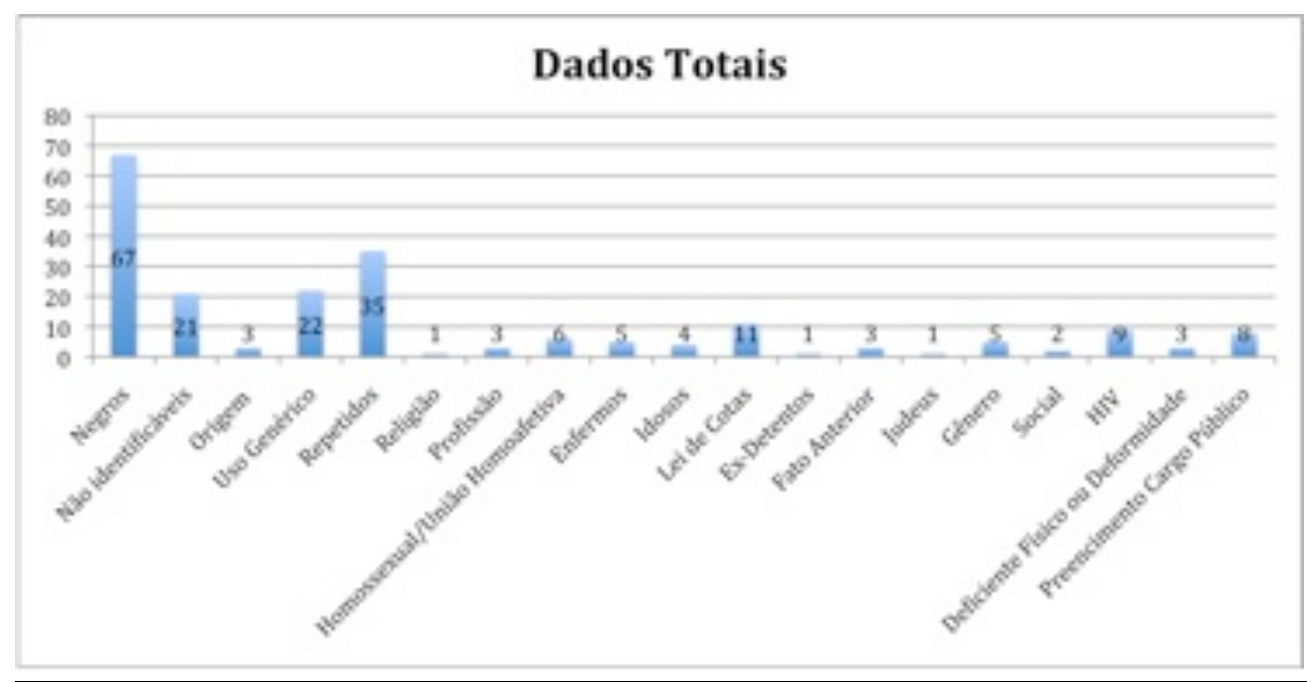


No caso dos processos cíveis, após a visualização dos dados brutos, ou seja, sem a análise de quantos processos apresentavam mais de um recurso, resolvemos tabelar a quantidade depurada.

\section{Dados sem a contabilização dos processos repetidos:}

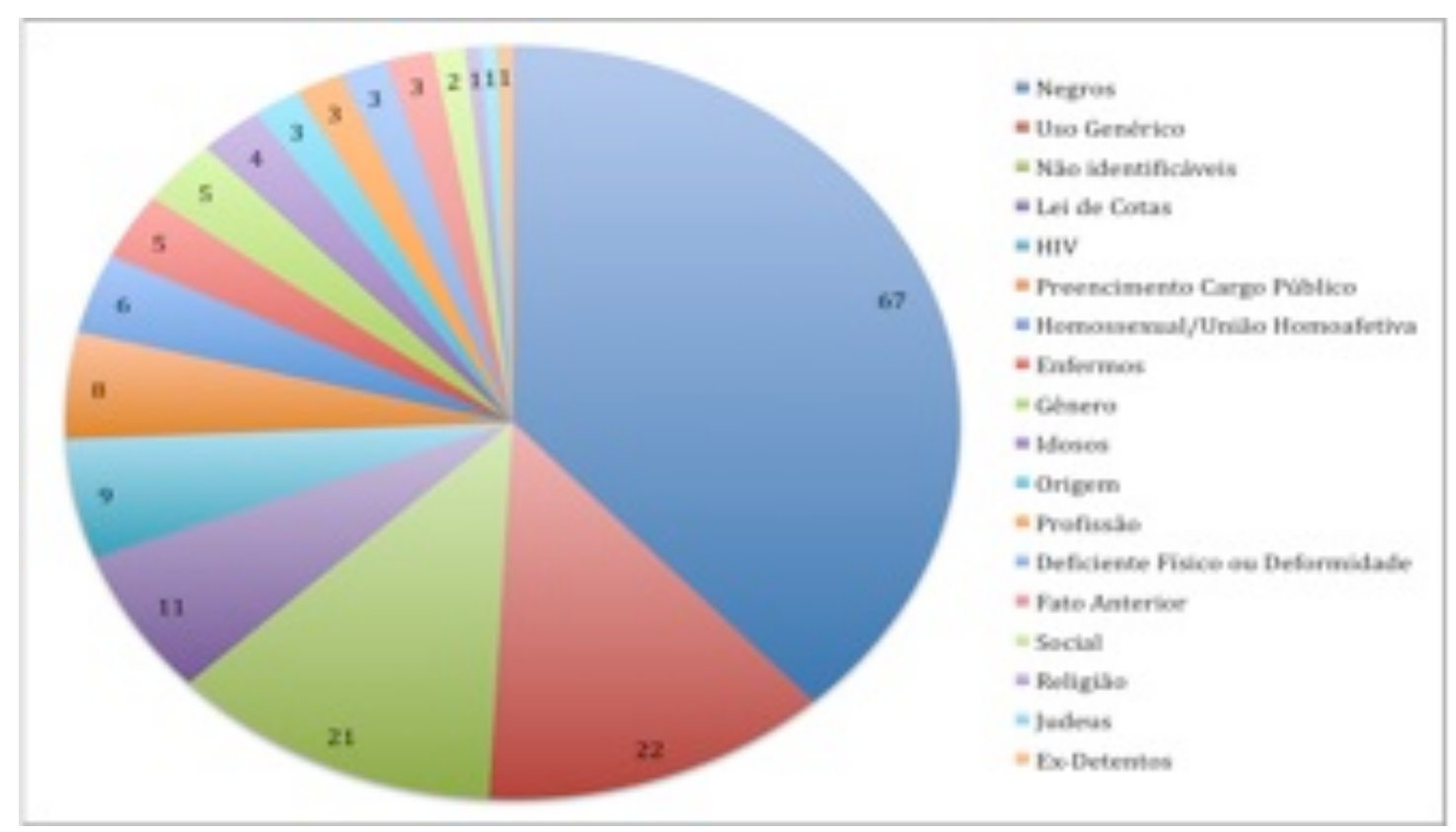

Legenda:

“Negros": Processos envolvendo Negros.

“Não identificáveis": Aqueles processos que apareceram como resultado em uma das palavras-chave, mas não foi possível identificar pelo acórdão qual tipo de discriminação ocorreu.

“Origem”: Processos a origem do indivíduo: oriental, indígena, nordestina etc.

“Uso Genérico": Quando a palavra-chave foi usada no sentido popular ou de forma atécnica. Por exemplo, "tais fatos devem ser analisados sem preconceito" ou "o dano moral deve ser aplicado sem preconceito".

“Repetidos": Considerados aqui os processos que, por ventura, apareceram como resultado de pesquisa em mais de uma palavra-chave.

“Religião": Processos abordando formas de religião.

"Profissãa”: Processos em que o indivíduo sofreu ou supôs estar sofrendo algum tipo em função de sua profissão. Nos 3 casos encontrados as profissões citadas foram tecnólogo em gás e petróleo, empregada doméstica e pintor.

“Homossexual/União Homoafetiva”: Processos envolvendo indivíduos homossexuais ou união homoafetiva.

"Enfermos": Processos que versam sobre a vedação de se condicionar o fornecimento de medicamentos por parte do Estado ou Município à apresentação de receituário médico expedido pela rede pública de saúde.

“Idosos": Processos abordando idosos.

"Lei de Cotas": Processos abordando a lei de cotas estadual.

“Ex-detentos”: Processos abordando ex-detentos. 
"Fato anterior": Processos em que o indivíduo sofre discriminação graças a um fato anterior ocorrido em sua vida. Os 3 casos encontrados foram problema de saúde psíquica, réu em ação penal anterior ajuizada em JECrim e gravidez.

“Judeus”: Processos envolvendo Judeus.

"Social": Processos abordando a "classe" social do indivíduo.

“Portadores de HIV": Processos abordando discriminação contra portadores do vírus HIV.

“Deficiente Físico ou Deformidade”: Processos envolvendo deficientes físicos ou indivíduos com deformidade física.

“Preenchimento de Cargo Público”: Processos questionando regras estabelecidas em editais de concurso público. Por exemplo, altura pré-determinada ou necessidade de exame psicotécnico.

Apesar de iniciarmos a pesquisa com julgados a partir do advento da Lei Caó, ressaltamos o fato de que entre os anos de 1989 e 1993 não há registros de processos envolvendo discriminação contra negros. A distribuição de processos por ano pode ser sintetizada na tabela abaixo.

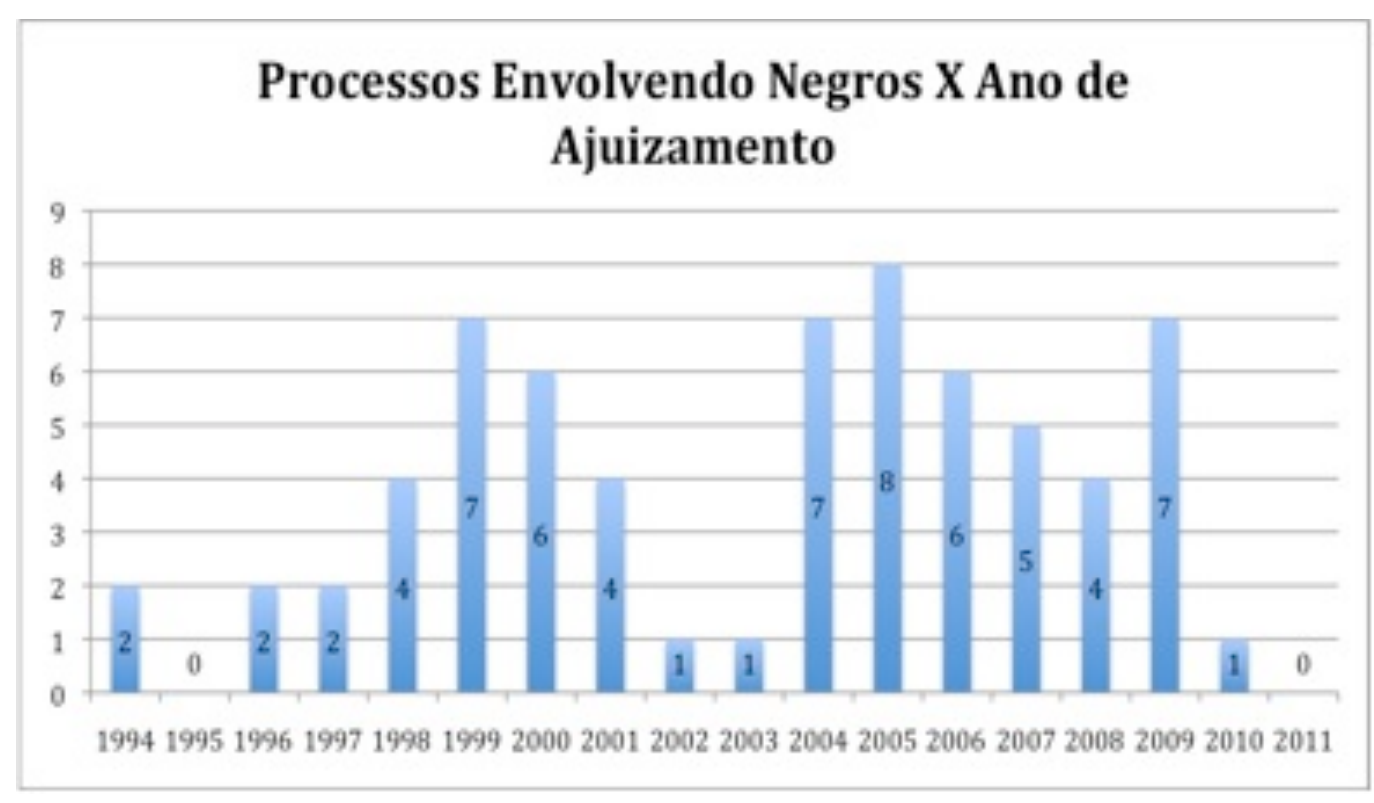

Após a depuração dos dados iniciais, chegamos ao número de 48 processos criminais e 67 processos cíveis. Optamos por, em uma primeira etapa da pesquisa, analisar somente os processos na seara criminal. Com isso, a extração dos dados apresentados no presente trabalho foi realizada sobre os 48 acórdãos criminais. 
Algumas observações são necessárias antes da análise dos dados. Primeiramente, importante ressaltar a mudança ocorrida no texto do Art. 145, Parágrafo Único do Código Penal em 2009, conforme se vê abaixo:

Parágrafo único-Procede-se mediante requisição do Ministro da Justiça, no caso do n. ${ }^{\circ}$ I do art. 141 , e mediante representação do ofendido, no caso do $n .^{\circ}$ II do mesmo artigo.

Parágrafo único. Procede-se mediante requisição do Ministro da Justiça, no caso do inciso I do caput do art. 141 deste Código, e mediante representação do ofendido, no caso do inciso II do mesmo artigo, bem como no caso do $\S 3^{\circ}$ do art. 140 deste Código. (Redação dada pela Lei ${ }^{\circ} 12.033$. de 2009)

"Art. 140. Injuriar alguém, ofendendo-lhe a dignidade ou o decoro:

(...) $§ 3^{\circ}$ Se a injúria consiste na utilização de elementos referentes à raça, cor, etnia, religião, origem ou condição de pessoa idosa ou portadora de deficiência:"

"Art. 141.As penas cominadas neste Capítulo aumentam-se de um terço, se qualquer dos crimes é cometido:

(...)II - contra funcionário público, em razão de suas funções;"

Com isso, a partir de 30/09/2009, data de publicação da Lei modificadora, os crimes de injúria qualificada passaram a ser persequíveis por ação penal pública condicionada à representação do ofendido. É por esse motivo que, nas condutas ocorridas em data anterior, hipótese de muitos processos analisados, vimos a propositura de uma queixa-crime e não de uma denúncia. Pelo mesmo motivo, há uma ressalva quando o MP é parte da ação em função da vítima ser funcionário público.

Também, relevante informar que, sempre que possível, as informações retiradas para a presente análise foram alcançadas no andamento processual de $1^{a}$ instância, com exceção, obviamente, daqueles processos já arquivados.

Em relação à quantidade de processos, após a primeira fase do levantamento de dados, foram selecionados 51 (cinquenta e um) processos que se relacionavam diretamente ao objeto da pesquisa. Desses 51 (cinquenta e um), 46 (quarenta e seis) tiveram os acórdãos analisados. Isso ocorre porque 2 (dois)processos foram arquivados nas duas instâncias, não tendo acórdão disponível e os demais tratavam-se de outros recursos em processos que já haviam sido analisados. 
Abaixo seguem os dados finais recolhidos para cada um dos seis questionamentos.

\section{Qual o tempo total de tramitação do processo até o julgamento em}

\section{$2^{\mathrm{a}}$ instância?}

Tomando como ponto de partida o período de 35 meses $^{67}$ em média para tramitação do processo até seu julgamento em sede recursal, estabelecemos o tempo total de tramitação dos processos objeto da análise, observando se houve uma demora desproporcional na apreciação.

Tendo em vista que muitos processos já foram arquivados em $1^{\mathrm{a}}$ instância, tornou-se quase impossível apontar a data em que a inicial foi distribuída. Sendo assim, estabelecemos 3 (três) maneiras de calcular a média do tempo de tramitação da ação.

a) média geral de todas os processos analisados, considerando aqueles em que não há como saber a data exata de ajuizamento, como se houvessem sido distribuídos no último dia do ano correspondente. P.ex.: Proc. n. 0011005-80.2001.8.19.0001 - consideramos como data inicial 21/12/2001.

\section{6 processos considerados.}

\section{Média de 28 meses para julgamento.}

b) média dos processos em que houve apelação. Consideramos aqui a apelação como o recurso mais exato para se estabelecer o término da ação. Os demais recursos ou ações autônomas, como recurso em

\footnotetext{
${ }^{67}$ Para chegarmos a esse número, levamos em conta dois fatores: a) a declaração do Des. Manoel Alberto Rebêlo dos Santos ao Anuário da Justiça do Rio de Janeiro de 2011 de que o tempo médio de tramitação dos processos em primeira instância, até o julgamento, no TJ-RJ é de 32 meses, sem discriminar os processos entre criminais e cíveis e b) o levantamento feito por nós, com base nos relatórios disponibilizados no sítio eletrônico do Tribunal, do tempo médio (em 2011) de pouco mais de 3 meses para julgamento em sede recursal de recursos criminais. Disponível em http://www.tjrj.jus.br/web/guest/produtividade-pjrj/anuario-2011/geral-segunda-inst-anuario-2011. Acesso em 24 fev. 2012.
} 
sentido estrito e habeas corpus, por vezes servem como etapas da ação.

\section{0 processos considerados.}

\section{Média de 30 meses para julgamento.}

c) média apenas dos processos com apelação julgada e que foi possível estabelecer data exata de início.

\section{6 processos considerados.}

\section{Média de 42 meses para julgamento.}

Se tomarmos como base os processos dentre os quais conseguimos determinar a data exata de sua distribuição, observamos um aumento de 7 (sete) meses na tramitação total dos processos envolvendo discriminação racial.

\section{Qual o tipo de defesa utilizada pelo autor: advocacia privada,}

\section{advocacia popular ou Defensoria Pública?}

O objetivo ao levantarmos essa questão foi suscitar um fator econômico entre as vítimas de discriminação, tendo em vista que, dependendo do tipo de defesa utilizada, depreendemos pela experiência uma diferença na relação entre vítima e patrono. Nos explicamos melhor. A vítima atendida pela Defensoria Pública, por exemplo, não possui uma personalização em seu atendimento graças ao grande volume de trabalho da Defensoria, o que pode influir na qualidade de sua argumentação jurídica.

No entanto, mais uma vez, não foi possível recolher com exatidão esse tipo de informação. 


\section{Tipo de Defesa}

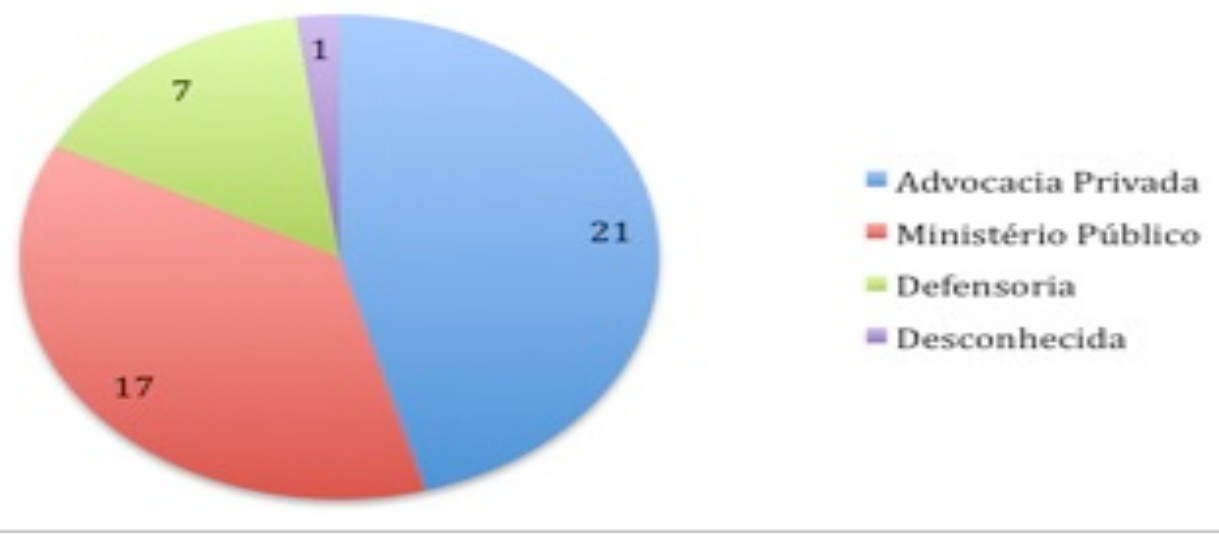

Não foi possível estabelecer se a defesa utilizada foi advocacia popular, já que na designação do patrono só havia nomenclatura específica quando se tratava da Defensoria Pública e do Ministério Público.

Não foi encontrada nenhuma denúncia oferecida após a mudança da lei que transferiu a titularidade da ação referente à injúria qualificada para o Ministério Público. Dentre os 16 (dezesseis) processos relacionados ao MP, 7 (sete) são em função da vítima ser funcionário público ${ }^{68} ; 3$ (três) por serem denúncia com base na L. 7716/89 (Lei Caó); 5 (cinco) foram aditamentos que o MP houve por bem fazer e retomar a titularidade da ação após a modificação de 2009 e, por fim, 2 (dois) estavam relacionados a outro crime que não a injúria qualificada ou o de racismo previsto na Lei Caó, mas que citam haver um comportamento discriminatório contra negros ${ }^{69}$.

Em um dos processos não foi possível identificar o tipo de defesa utilizada, pois não havia indicação no andamento processual de segunda instância e nem qualquer menção no acórdão. Soube-se que o processo foi originado de uma queixa-crime, mas pode ter sido patrocinado tanto por um advogado particular quanto pela Defensoria Pública.

\footnotetext{
${ }^{68} \mathrm{Em}$ um dos processos, apesar de injúrias de cunho racial serem proferidas, o réu é denunciado apenas por desacato.

${ }^{69} \mathrm{Um}$ processo sugere que um dos acusados foi preso pelo fato de ser "negro, simples e gordo" e o outro diz respeito a um homicídio julgado pela Justiça Militar onde o desembargador dá a entender que o acusado só atirou na vítima por ela ser negra e prejulgar que oferecia perigo.
} 
Pudemos ver que na maioria dos casos analisados a defesa foi executada por advocacia privada. Partindo do princípio que essas vítimas possuíam uma situação sócio-econômica mais privilegiada, em comparação com aquelas que precisam utilizar a advocacia pública, podemos suscitar uma questão de acesso à justiça. Ou seja, a possibilidade de vítimas em situação sócio-econômica menos privilegiada não procurarem o Judiciário para dirimir conflitos raciais, fato que procurou ser dirimido pelo legislador ao modificar a lei e definir que a injúria qualificada é persequível por ação penal pública condicionada a representação do ofendido. $\mathrm{O}$ fator surpreendente foi não encontrarmos nenhuma denúncia oferecida pelo Ministério Público após a modificação da legislação.

\section{III e IV. Nos casos em que o réu era branco, como a conduta foi tipificada? Dos casos que o réu era negro, como foi tipificada?}

A ideia inicial ao estabelecermos tais questionamentos foi analisar se haveria uma tipificação diferente - leia-se mais branda - para os casos em que o réu fosse branco.

Entretanto, é praticamente impossível definir a cor dos réus. Isso só foi possível em 5 (cinco) processos, dos quais 2 (dois) tinham como réus pessoas famosas $^{70}$ (ambas categorizadas como "pardas") e os 3 (três) restantes foram passíveis de identificação por alguma menção no texto do acórdão (sendo um dos réus considerado branco e os demais negros).

Apesar da dificuldade em identificar a cor do réu, foi possível estabelecer a tipificação utilizada em cada processo.

Importante ressaltar a diferença encontrada entre os delitos de injúria qualificada, prevista no Art. $140, \S 3^{\circ}$ do Código Penal, introduzida pela Lei 9.459/97, e o de racismo, previsto, entre outros, no Art. 20 da Lei 7.716/89, também conhecida como Lei Caó.

\footnotetext{
${ }^{70}$ Chico Anysio e Tiririca.
} 
A doutrina explica que, sendo a ofensa dirigida a uma pessoa apenas e com a vontade livre e consciente de ofender a honra, ou seja, com o dolo de injuriar, a conduta se enquadra no tipo de injúria qualificada. Já no caso do delito de racismo previsto no Art. 20 da Lei Caó, mesmo que a ofensa seja dirigida a uma pessoa, "está revelando inequivocamente um preconceito em relação à raça negra, ou aos que possuam a 'cor preta', pois a expressão utilizada contém o raciocínio de que todo negro ou preto faz coisas erradas" ${ }^{\text {,71 }}$. Em suma, para a conduta se enquadrar no tipo penal da Lei Caó, há a necessidade da "comprovação de três elementos (1) evidência direta do ato discriminatório (2) evidência direta da discriminação do ofensor para o ofendido e (3) evidência da relação de causalidade entre aqueles. que a atitude do agressor foi com a intenção de discriminar racialmente ${ }^{72}$,

O gráfico abaixo mostra a tipificação considerada principal, ou seja, aplicação da injúria qualificada e do crime de racismo pela Lei Caó, e as demais tipificações recebidas.

Percebe-se que o número total de tipificações supera o número de acórdãos analisados. Isso se deve ao fato de que em 8 (oito) processos, o réu foi acusado de algum outro crime além da injúria qualificada ou do racismo.

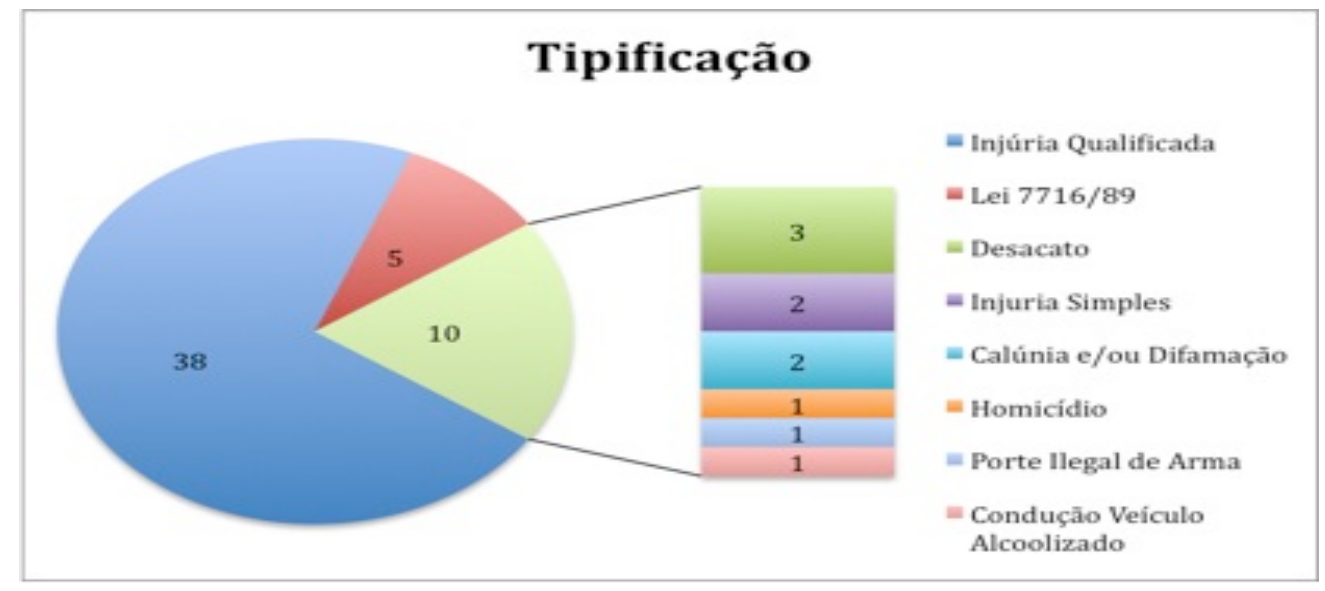

\footnotetext{
${ }^{71}$ SANTOS, Christiano Jorge. Crimes de preconceito e de discriminação. p. 142.

${ }^{72}$ CIDH. Caso Simone André Diniz vs. Brasil, petição 12.001. Aprovado pelo Relatório 66/06, em $21 / 11 / 2006$.
} 


\section{Foi aplicada a agravante genérica do art. 61, II, "a" do}

\section{Código Penal?}

Partimos do princípio que, estando as penas de injúria racial (Art. 140, $\S 3^{\circ}, \mathrm{CP}$ ) e racismo (Art. 20, L. 7.716/89) em pé de igualdade, o fato do delito de racismo localizar-se em uma lei especial não o dá um status de maior severidade àquele tipificado no Código Penal.

Com isso e, considerando a gravidade do delito racial e a repugnância que deveria suscitar no corpo social, cogitamos a possibilidade da aplicação de tal dispositivo.

Cabe explicar que a agravante genérica é aplicada desde que a circunstância não constitua ou qualifique o delito. Motivo fútil é aquele "insignificante, mesquinho, constituindo-se muitas vezes num pretexto gratuito e inadequado ${ }^{73}$ ", já motive torpe é "o motivo abjeto, indigno, imoral, que suscita repugnância e é próprio de personalidades profundamente antisociais $^{74,}$.

“Art. 61. São circunstâncias que sempre agravam a pena, quando não constituem ou qualificam o crime:

(...)II - ter o agente cometido crime:

a) por motivo fútil ou torpe"

Entretanto, em nenhum processo analisado foi utilizada a agravante genérica do Art. 61, II, a. Apenas em um processo foi utilizada uma das agravantes do Art. 61, mas em razão da ofensa ter sido proferida contra criança (Inc. II, alínea ' $h$ ') e, mesmo assim, ao que parece, a decisão em $2^{\mathrm{a}}$ instância desconsiderou a aplicação.

Levando-se em conta que, de forma geral, só foram utilizadas três causas especiais de aumento de pena, todas previstas no Art. 141, incisos II, III e IV (respectivamente, em razão da vítima ser funcionário público, pela ofensa ser proferida na presença de 3 (três) ou mais pessoas e pela vítima ser idoso) e

\footnotetext{
${ }^{73}$ MIRABETE, Julio Fabbrini \& FABBRINI, Renato N. Manual de direito penal, volume 1: parte geral. São Paulo: Atlas, 2008. p. 302.

${ }^{74}$ Ibid.
} 
que em 8 (oito) processos os crimes não foram tipificados como injúria qualificada, no gráfico abaixo serão considerados 38 acórdãos.

Lembrando ser indiferente se o acusado foi condenado ou não. Aqui leva-se em conta se a denúncia/queixa-crime suscitou a causa de aumento de pena.

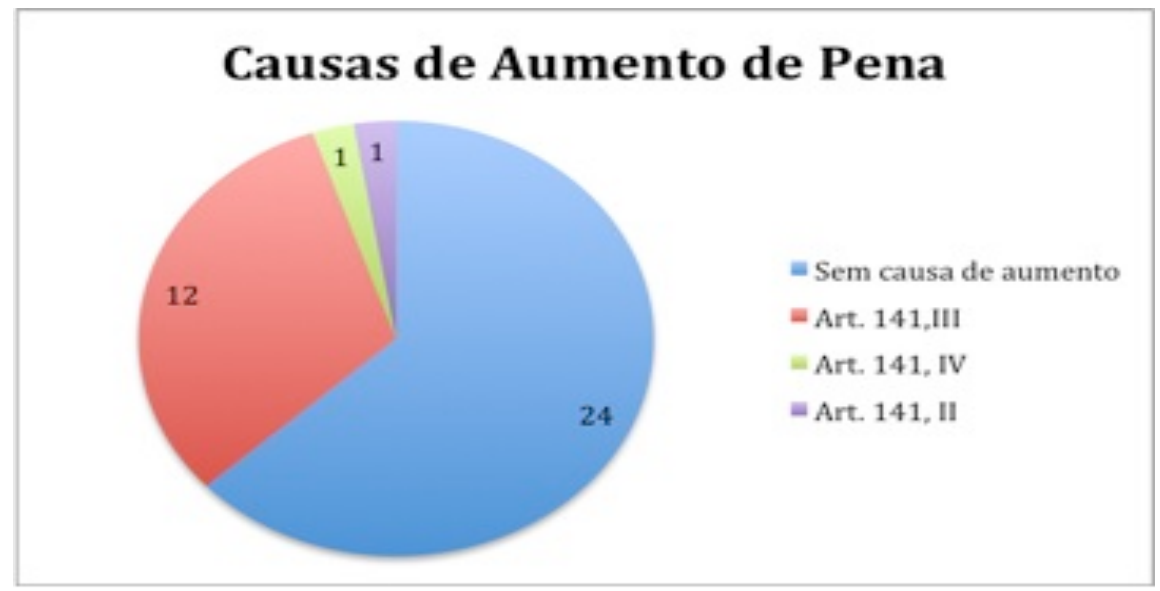

\section{Quem ganhou a ação?}

Nesse último questionamento, alcançaríamos uma convergência de todos os dados anteriormente levantamos. Com isso, procuraríamos definir, por exemplo, se a vítima hipossuficiente (atendida pala Defensoria Pública ou por advocacia popular), ao demandar (suscitar crime de racismo conforme o art. 20, L. 7.716/89) contra um réu (branco), obteria sucesso em sua argumentação.

No entanto, como não foi possível levantar com precisão os dados anteriores, restou de importância ressaltar que, dentre os 5 (cinco) processos em que a conduta foi tipificada na Lei Caó, não houve nenhuma condenação.

Aqui são considerados apenas os processos em que a tipificação foi de injúria qualificada ou do crime de racismo pela Lei Caó, seja em concurso com outro crime ou não. Logo, foram considerados 42 acórdãos. 


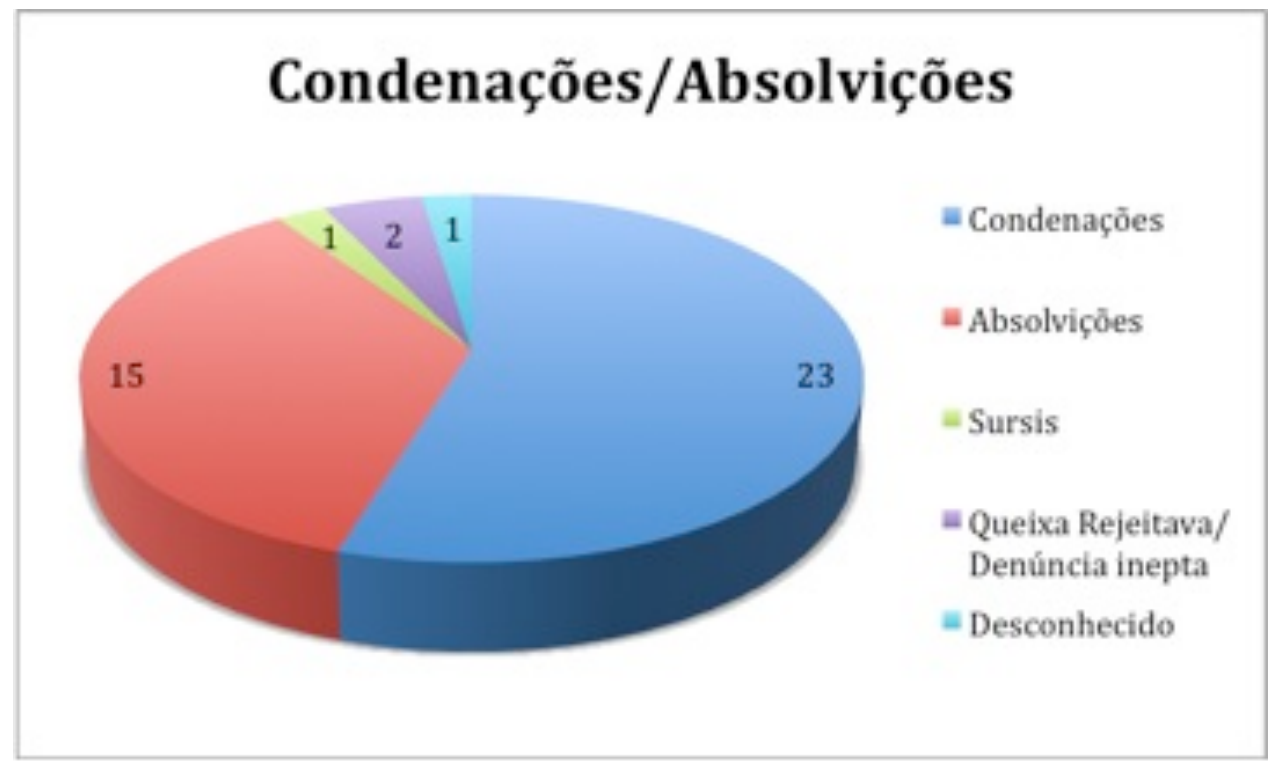

Para um melhor esclarecimento, temos um processo categorizado como "desconhecido" porque houve um HC julgado e que opinou pelo prosseguimento da ação penal, mas com o arquivamento em $1^{\mathrm{a}}$ instância, não há como obter maiores informações.

Também não consideramos para fins de condenação ou absolvição uma queixa-crime rejeitada por considerar que a titularidade da ação era do MP e uma denúncia tida como inepta por considerar que o crime cometido deveria ser tipificado na Lei de Imprensa e não na Lei Caó.

Podemos dizer que, em vigor na prática forense, há dois dispositivos legais que deveriam ter como objetivo o combate à práticas discriminatórias: a Lei 7.716/89 e o delito de injúria qualificada pelo preconceito contido no art. 140, §3o ao Código Penal. Entretanto, é possível ver claramente o que a Teoria Crítica da Raça diz ao afirmar que o direito define o racismo: doutrina e jurisprudência lhes dão interpretações distintas, definindo de forma tendenciosa quais condutas devem ser enquadradas na Lei Caó e quais condutas devem ser enquadradas como injúria qualificada.

E aqui está a maior barreira para a utilização da Lei 7.716/89. É inegável a dificuldade encontrada para provar que a ofensa proferida está 
direcionada à "raça" negra como um todo, e não constitui apenas ofensa à honra subjetiva do indivíduo. Até mesmo no que diz respeito à injúria qualificada, a matéria probatória também é um empecilho, tendo em vista ser extremamente difícil comprovar a intenção de ofender do acusado (dolo), gerando absolvições por insuficiência de provas.

Ao observarmos que, em cerca de $60 \%$ (sessenta por cento) dos acórdãos analisados, a predileção dos magistrados foi por tipificar o ilícito cometido como injúria qualificada, contida no Art. 140, §3o do Código Penal, delito suscetível à prescrição, por exemplo, diferentemente do que ocorre com o crime previsto no Art. 20 da Lei 7.716/89, observamos um abrandamento na aplicação da lei. Tal afirmação pode ser analisada, por exemplo, nos acórdãos de $\mathrm{n}^{\mathrm{o}} \quad 0132379-29.2002 .8 .10 .0001(2003.050 .04038)$ e no 001665142.1999.8.19.0001 (2000.050.04827).

No primeiro caso, a ré apela após ser condenada em $1^{\text {a }}$ instância por injúria qualificada. A ré, ao supor que a vítima agrediu seus animais de estimação, proferiu as seguintes palavras: "negro nojento, asqueroso, peste negra...lugar de negro é na senzala". Em primeiro lugar, não conseguimos entender porque tais dizeres não se enquadram no tipo penal mais gravoso da Lei Caó, tendo em vista que ao dizer, por exemplo, que "lugar de negro é na senzala", a ré não procura mais ofender apenas a honra vítima, aumentando seu âmbito de ação para todos de cor negra. Ao fim do julgamento, a ré foi absolvida sob o argumento de que "ao ver seus animais de estimação sendo maltratados pelo Apelado, uma cólera tomou conta da Apelante, que, envolvida por forte emoção acabou desabafando".

No segundo caso, após desentendimentos entre as partes, o réu proferiu as seguintes palavras "preto de merda". O réu foi condenado por injúria simples (art. 140, caput, Código Penal) sob o argumento de que "nem toda expressão como 'preto de merda' [...] será informada pela nota do preconceito. 
[...] O primeiro elemento é apenas designativo, indicador do destinatário da ofensa".

Em nossa opinião, resta clara a influência de um racismo estrutural que se manifesta através de atores institucionais. Em ambos os casos, as ofensas são tidas como tão naturais, que os desembargadores não conseguem considerá-las com a devida gravidade. É significativo observar que, apesar de todo o aparato legal e teórico de exclusão construído no país desde o início da colonização portuguesa, a prática do racismo contra negros não conseguiu alcançar o patamar de repugnância necessário para que medidas judiciais mais severas fossem aplicadas.

Outro indício importante da complacência da jurisprudência face um crime tão grave como o de racismo está nas condenações. Pudemos observar que em cerca de $54 \%$ (cinquenta e quatro por centro) dos casos, o réu foi condenado. Entretanto, dentre os acórdão analisados, não foi encontrada qualquer condenação com base na Lei 7.716/89 e apenas 6 (seis) acórdãos trataram de denúncias baseadas na referida legislação.

Não bastando, a condenação não significou necessariamente o cumprimento de pena privativa de liberdade. Todos os condenados (em sua totalidade por injúria qualificada) obtiveram o benefício da sursis, tendo suas penas convertidas em penas restritivas de direito. 


\section{Conclusão}

O presente trabalho demonstrou como, ao longo de quase 14 (quatorze) séculos, negros vem sendo vítimas de um processo de exclusão que, por boa parte desse período, foi "naturalizado". Não bastando, vimos como a legislação foi utilizada como braço prático de tal mecanismo.

Apesar dos avanços alcançados no âmbito constitucional no Brasil, principalmente com a Carta Magna de 1988, ainda não conseguimos superar as dificuldades nas relações raciais que, no âmbito local, acumulam-se desde a escravidão.

Encontramos como um dos maiores obstáculos para superar esse sistema a subjetividade de se definir quais são as ações excludentes. Para definirmo-las, ficamos dependentes de atores sociais que estão arraigados de conceitos que normalizam essas exclusões.

Tais circunstâncias podem ser exemplificadas a partir da pesquisa realizada com os processos criminais julgados em segunda instância no Tribunal de Justiça do Rio de Janeiro ao demonstrarem como, apesar da existência dos mecanismos formais de combate ao racismo, os efeitos ficam dependendo do entendimento de juízes e desembargadores.

Conforme demonstramos, a prática de condutas discriminatórias não são passíveis de uma severidade maior em sua punição. A título exemplificativo, um furto simples, possui uma cominação de pena maior que o de racismo. Punimos mais severamente um crime patrimonial do que um crime que ofende um bem jurídico tão relevante, qual seja a dignidade da pessoa humana e a isonomia material.

Muito embora nos tenha permitido observações importantes, podemos concluir que, em função das informações precárias encontradas no corpo dos acórdãos, não foi possível afirmarmos que todas as interpretações dadas pelos 
desembargadores estão calcadas em um racismo estrutural ou, até mesmo, um racismo institucional, se fazendo necessário um maior aprofundamento e uma maior abrangência em seu levantamento, o que poderá ser alcançado em uma etapa futura da pesquisa através de uma definição de grupos menores de acórdãos, possibilitando uma análise mais detalhada, inclusive optando pela pesquisa de campo para suprimir as possíveis lacunas.

No entanto, nos torna possível afirmar, a reboque dos mecanismos de ação afirmativa cada vez mais utilizados dentro do ordenamento brasileiro, fazse necessária uma melhor definição do âmbito de atuação dos dois dispositivos - Art. 140, §3o, CP e Lei 7.716/89 -, de forma a não deixar que crimes que ofendem um bem jurídico tão relevante, qual seja a dignidade da pessoa humana e a isonomia material, sejam definidos por interpretações jurisprudenciais desconexas. Para além disso, precisamos de uma mudança de paradigma. 


\section{Bibliografia}

ALENCASTRO, Luiz Felipe de. O trato dos viventes: formação do Brasil no Atlântico Sul. São Paulo: Companhia das Letras, 2000.

ALVES FILHO, Aluizio. Manoel Bomfim - combate ao racismo, educação popular e democracia radical. São Paulo: Editora Expressão Popular, 2008.

AUGUSTO, Cristiane Brandão. \& ORTEGA, Francisco. Nina Rodrigues e a patologização do crime no Brasil. Disponível em $<$ http://www.scielo.br/scielo.php?pid=S180824322011000100011\&script=sci arttext $>$.Acessoem $21 \mathrm{mar} .2012$.

BOMFIM, Manoel. América Latina: males de origem. Centro Edelstein de Pesquisas Sociais. Rio de Janeiro, 2008. Disponível em $<$ http://www.do.ufgd.edu.br/MarioJunior/arquivos/BOMFIM_A_America_Lati na_Males_de_origem.pdf $>$. Acesso em 05 mai. 2012.

CHAISSON, Rena L. A Crack In the Door: Critical Theory In Practice at a Predominantly White Institution. Theaching Sociology, Vol. 32, no 4, pp. 345357, Outubro 2004.

CRENSHAW, Kimberle Williams. Race, Reform, and Retrenchment: Transformation and Legitimation in Antidiscrimination Law. In Harvard Law Review, Vol. 101, No. 7, pp. 1331- 1387, Maio 1988.

FERREIRA, Denise. Facts of Blackness: Brazil is not (Quite) the United States... and Racial Politics in Brazil? In Social Identities, Volume 4, Number 2, University of Pittsburg, 1998.

GUIMARAES, Antonio Sergio Alfredo. Preconceito de cor e racismo no Brasil. Rev. Antropol. vol.47 no.1 São Paulo, 2004. Disponível em http://www.scielo.br/scielo.php? script $=$ sci_arttext\&pid=S003477012004000100001\&lang=pt, Acesso em 13 abr. 2012.

GUTMAN, Guilherme. Raça e psicanálise no Brasil. O ponto de origem: Arthur Ramos. Rev. latinoam. psicopatol. fundam. vol.10 no.4 São Paulo Dec. 2007. Disponível em http://www.scielo.br/scielo.php?pid=S141547142007000400014\&script=sci_arttext. Acesso em 29 de março de 2012.

HARRIS, Cheryl I. Critical Race Studies: An Introduction. In 49 UCLA Law Review.pp. 1215- 1222. Junho 2002. 
HOFBAUER, Andreas. Uma história de branqueamento ou o negro em questão. São Paulo: Editora UNESP, 2006.

LENZA, Pedro. Direito constitucional esquematizado. 13. ed. rev. atual. e ampl. São Paulo: Saraiva, 2009.

JACCOUD, Juliana \& BEGHIN, Nathalie. Desigualdades raciais no Brasil: um balanço na intervenção governamental. Brasília: Ipea, 2002.

MAIO, Marcos Chor. O Projeto Unesco e a agenda das Ciências Sociais no Brasil dos anos 40 e 50. in M. C. Maio e R. V. Santos (orgs.). Raça, Ciência e Sociedade. Rio de Janeiro, Fiocruz/Centro Cultural Banco do Brasil, 1996. Disponível em http://www.scielo.br/scielo.php? script $=$ sci_arttext\&pid=S010269091999000300009\&lang=pt Acesso em 28 de maio de 2012 .

MIRABETE, Julio Fabbrini \& FABBRINI, Renato N. Manual de direito penal, volume 1: parte geral. São Paulo: Atlas, 2008. p. 302.

NOGUEIRA, Oracy. Preconceito racial de marca e preconceito racial de origem: sugestão de um quadro de referência para a interpretação do material sobre relações raciais no Brasil. Tempo soc. vol.19 no.1 São Paulo June 2007. Disponível em $\quad<$ http://www.scielo.br/scielo.php? script $=$ sci_arttext\&pid $=\mathrm{S} 010320702007000100015 \&$ lang $=\mathrm{pt}>$. Acesso em 06 mar. 2012.

NASCIMENTO, Abdias. Teatro experimental do negro: trajetória e reflexões. Estud. av. vol.18 no.50. São Paulo, Jan./Apr. 2004.Disponível em http://www.scielo.br/scielo.php?script=sci_arttext\&pid=S01034014200400010 0019\&lang=pt Acesso em 10 de junho de 2011.

NASCIMENTO, Abdias \& NASCIMENTO, Elisa Larkin. Reflexões sobre o Movimento Negro no Brasil, 1938-1997. In. GUIMARÃES, Antonio Sérgio Alfredo \& HUNTLEY, Lynn. (Orgs.) Tirando a Máscara: Ensaios sobre o Racismo no Brasil. São Paulo. Paz e Terra/SEF. 2000. PP. 203-236

PAIXÃO, Marcelo. Manifesto Anti-Racista: ideias em prol de uma utopia chamada Brasil. 1a ed. Rio de Janeiro: DP\&A; LPP/UERJ, 2006.

SANTOS, Christiano Jorge. Crimes de preconceito e de discriminação. 2a ed. São Paulo: Saraiva, 2010. 
SILVA JÚNIOR, Hédio. Do racismo legal ao princípio da ação afirmativa: a lei como obstáculo e como instrumento dos direitos e interesses do povo negro. In: GUIMARÃES, Antônio Sérgio A.; HUNTLEY, Lynn. Tirando a máscara: ensaio sobre o racismo no Brasil. São Paulo: Paz e Terra, 2000.

. Reflexões sobre a aplicabilidade da legislação anti-racismo. In: SABOIA, Gilberto Vergne (Org.). In: Seminários Regionais Preparatórios para Conferência Mundial Contra Racismo, Discriminação Racial, Xenofobia e Intolerância Correlata. Anais. Brasília, Ministério da Justiça, 2001.

SOLORZANO, Daniel. CEJA, Miguel. YOSSO, Tara. Critical Race Theory, Racial Microaggressions, and Campus Racial Climate: The Experiences of African American College Students.The Journal of Negro Education, Vol. 69, No. 1/2.pp. 60-73. Winter - Spring, 2000.

TAYLOR, Edward. A Primer on Critical Race Theory.The Journal of Blacks in Higher Education, No. 19.The JBHE Foundation.pp. 122-124. Spring 1998.

WIEVIORKA, Michael. O racismo, uma introdução. São Paulo: Perspectiva, 2007. 